This is the peer-reviewed version of the paper:

Spasojević, M., Marković, D., Trišović, T., Spasojević, M., 2018. Mathematical model of the catalytic effect of chromium(VI) on hypochlorite disproportionation in chlorate electrolysis. Journal of the Electrochemical Society 165, E8-E19.

https://doi.org/10.1149/2.0291802jes

\title{
(9) $(\mathbb{Q} \Theta \Theta$
}

This work is licensed under the Attribution-NonCommercial-NoDerivatives 4.0 International (CC BY-NC-ND 4.0) 


\title{
Mathematical Model of the Catalytic Effect of Chromium(VI) on Hypochlorite Disproportionation in Chlorate Electrolysis
}

\author{
M. Spasojević, ${ }^{1}$ D. Marković, ${ }^{1}$ T. Trišović, ${ }^{2}$ and Milica Spasojević ${ }^{3}$ \\ ${ }^{1}$ Joint Laboratory for Advanced Materials of SASA, Faculty of Technical Sciences, Čačak, University of Kragujevac, \\ Čačak, Serbia \\ ${ }^{2}$ Institute of Technical Sciences of the Serbian Academy of Sciences and Arts, Belgrade, Serbia \\ ${ }^{3}$ Faculty of Chemistry, University of Belgrade, Belgrade, Serbia
}

\begin{abstract}
The effect of chromium(VI) on the kinetics of disproportionation of hypochlorous acid and hypochlorite was established in the solution for the electrolytic production of chlorate. The hexavalent chromium species $\mathrm{Cr}_{2} \mathrm{O}_{7}{ }^{2-}, \mathrm{HCrO}_{4}{ }^{-}$and $\mathrm{CrO}_{4}{ }^{2-}$ present in the solution catalyze the disproportionation reaction. In both the absence and presence of chromium(VI), disproportionation is a third-order reaction with respect to $\mathrm{HClO}$ and $\mathrm{ClO}^{-}$, and a first-order reaction with respect to the hexavalent chromium species. In the presence of chromium(VI) ions, four parallel reactions probably take place in the solution i.e. uncatalyzed disproportionation and three parallel reactions catalyzed by $\mathrm{Cr}_{2} \mathrm{O}_{7}{ }^{2-}, \mathrm{HCrO}_{4}{ }^{-}$and $\mathrm{CrO}_{4}{ }^{2-}$ ions. Most likely, the hexavalent chromium species do not change the sequence of elementary reactions in the disproportionation mechanism but only speed up the rate-determining step through interaction with its reactants. In the chlorate production process, as chromium(VI) concentration increases, the optimum $\mathrm{pH}$ which ensures the maximum rate of disproportionation is shifted to an acid environment. This is due to an increase in the concentration of the catalytically most active species $\mathrm{HCrO}_{4}{ }^{-}$with increasing acidity of the solution. A mathematical model of the kinetics of the chromium(VI)-catalyzed disproportionation of hypochlorite and hypochlorous acid into chlorate was set up. Good agreement was obtained between theoretical and experimental data.
\end{abstract}

On an industrial scale, sodium chlorate is produced by the electrolysis of concentrated solutions of sodium chloride. ${ }^{1-3}$ In 2015 , sodium chlorate production totaled 3.6 million tons, whereof 3.2 million tons were used to make chlorine dioxide for the environmentally friendly elemental chlorine-free (ECF) bleaching of pulp. ${ }^{4}$ In the last $10-15$ years, the annual demand for sodium chlorate has increased by about $30 \%{ }^{4}$ The increase in consumption will probably continue as the use of tissue (kitchen rolls, bathroom tissue etc.) and packaging board increases. In modern industrial plants, current efficiency in the sodium chlorate process ranges from 94 to $96 \%$, and is limited by oxygen formation. ${ }^{2}$ Increasing the current efficiency by decreasing the oxygen evolution reaction could yield large economic savings due to the high annual production of sodium chlorate. A detailed description of the process and chemistry of the electrolytic production of chlorate is provided by H. Vogt et al., ${ }^{5}$ J. E. Colman and B. V. Tilak ${ }^{6}$ and N. Ibl and H. Vogt. ${ }^{7}$

During the electrolytic production of chlorate by the electrolysis of concentrated solutions of sodium chloride, elemental chlorine is evolved at the anode by the oxidation of chloride ions:

$$
2 \mathrm{Cl}^{-} \rightarrow \mathrm{Cl}_{2}+2 \mathrm{e} \quad \mathrm{E}^{\Theta}=1.359 \mathrm{~V}
$$

The chlorine evolved is quickly absorbed in the electrolyte and hydrolyzed to hypochlorous acid:

$$
\mathrm{Cl}_{2}+\mathrm{H}_{2} \mathrm{O} \rightarrow \mathrm{HClO}+\mathrm{H}^{+}+\mathrm{Cl}^{-} \quad \mathrm{pK}_{\mathrm{h}}=2.98
$$

The hydrolysis reaction is fast and, therefore, at $\mathrm{pH}$ values of the solution above 5.8, almost all the dissolved chlorine hydrolyzes near the anode. ${ }^{1-14}$ The cell gas contains less than $0.2 \%$ chlorine. In the solution, an equilibrium of the hypochlorous acid dissociation reaction is established:

$$
\mathrm{HClO} \rightleftharpoons \mathrm{H}^{+}+\mathrm{ClO}^{-} \quad \mathrm{K}_{3}=2 \cdot 10^{-7} \mathrm{~mol} \mathrm{dm}^{-3}\left(\mathrm{t}=70^{\circ} \mathrm{C}\right)
$$

In the bulk of the solution, hypochlorous acid and hypochlorite disproportionate into chlorate: ${ }^{1-15}$

$$
2 \mathrm{HClO}+\mathrm{ClO}^{-} \rightarrow \mathrm{ClO}_{3}^{-}+2 \mathrm{Cl}^{-}+2 \mathrm{H}^{+}
$$

Reaction 4 is a homogenous reaction, which under industrial conditions occurs at a maximum rate in the $\mathrm{pH}$ range of 6.1 to 6.5 at temperatures between 70 and $90^{\circ} \mathrm{C}^{1-14}$ This reaction intensifies chlorine evolution at a low $\mathrm{pH}$ and oxygen formation at a high $\mathrm{pH}$. A chlorate production plant typically features a large volume tank through which the reaction solution flows to allow Reaction 4 to reach high conversion. ${ }^{14-16}$ The temperature of the solution is set to a relatively high value in order to increase the rate of the chemical conversion of hypochlorous acid and hypochlorite into chlorate, and electrode reactions (to decrease cell voltage). ${ }^{9,14-17}$ However, increasing temperature leads to an increase in the rate of undesirable oxygen evolution reaction. Therefore, the optimum temperature which ensures maximum current efficiency must be determined.

Research has been conducted on the effect of solution $\mathrm{pH}$, solution temperature, and sodium chloride and sodium chlorate concentrations on the kinetics and mechanism of disproportionation of hypochlorous acid and hypochlorite. ${ }^{18-23}$ It has been shown that disproportionation

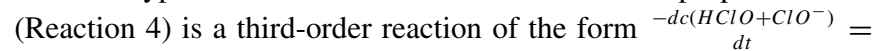
$\mathrm{k}_{1} \cdot \mathrm{C}^{2}(\mathrm{HClO}) \cdot \mathrm{C}\left(\mathrm{ClO}^{-}\right){ }^{22,23} \mathrm{~J}$. Wanngård and $\mathrm{M}$. Wildlock ${ }^{23}$ reported the rate constant $\mathrm{k}_{1}$ of $7.19 \mathrm{~mol}^{-2} \mathrm{dm}^{-6} \mathrm{~s}^{-1}$ in the solution containing $526 \mathrm{~g} \mathrm{dm}^{-3} \mathrm{NaClO}_{3}$ and $113 \mathrm{~g} \mathrm{dm}^{-3} \mathrm{NaCl}$ at $\mathrm{t}=70^{\circ} \mathrm{C}$.

In the bulk solution, a minor fraction of hypochlorous acid and hypochlorite is decomposed into oxygen and chloride ions:

$$
2 \mathrm{HOCl} \rightarrow \mathrm{O}_{2}+2 \mathrm{H}^{+}+2 \mathrm{Cl}^{-}
$$

$$
2 \mathrm{OCl}^{-} \rightarrow \mathrm{O}_{2}+2 \mathrm{Cl}^{-}
$$

The kinetics and mechanism of this side reaction have also been examined. ${ }^{22,24-28} \mathrm{~S}$. Sandin et al. ${ }^{22}$ determined that uncatalyzed oxygen formation is a third-order reaction with respect to hypochlorous acid and hypochlorite, which is dependent on the $\mathrm{pH}$ of the solution, similarly to the chlorate formation Reaction 4 . The rate constant for uncatalyzed oxygen formation by hypochlorite decomposition was found to be $0.046 \mathrm{~mol}^{-2} \mathrm{dm}^{-6} \mathrm{~s}^{-1}$, compared with that for chlorate formation of about $0.73 \mathrm{~mol}^{-2} \mathrm{dm}^{-6} \mathrm{~s}^{-1}$. S. Sandin et al. ${ }^{22}$ suggested that oxygen is formed via the same intermediate complex $\left[\mathrm{H}_{2} \mathrm{Cl}_{2} \mathrm{O}_{2}\right.$ or $\mathrm{HCl}_{2} \mathrm{O}_{2}{ }^{-}$] as chlorate. Also, no effect of ionic strength on the rate of Reactions 5 and 6 was determined. ${ }^{22}$ Based on the fact that the rate constant of chlorate formation by the disproportionation of hypochlorous acid and hypochlorite in concentrated chlorate and chloride solutions is over $7.1 \mathrm{~mol}^{-2} \mathrm{dm}^{-6} \mathrm{~s}^{-1}$ at $70^{\circ} \mathrm{C}, \mathrm{J}$. Wanngård and $\mathrm{M}$. Wildlock ${ }^{23}$ concluded that less than $1 \%$ of the hypochlorite reacts to oxygen in the bulk solution, and that homogeneous oxygen formation is neglected in the kinetic evolution.

As stated by a number of authors, ${ }^{7,10-13,16,17,29-31}$ most of the loss in current efficiency during chlorate production is caused by the anodic 
oxidation of hypochlorous ${ }^{23}$ acid and hypochlorite: ${ }^{23,31}$

$$
\begin{aligned}
& 6 \mathrm{ClO}^{-}+3 \mathrm{H}_{2} \mathrm{O} \rightarrow 1.5 \mathrm{O}_{2}+2 \mathrm{ClO}_{3}{ }^{-}+4 \mathrm{Cl}^{-}+6 \mathrm{H}^{+}+6 \mathrm{e} \\
& \mathrm{E}^{\Theta}=0.69 \mathrm{~V}
\end{aligned}
$$

$$
\begin{aligned}
& 6 \mathrm{HClO}+3 \mathrm{H}_{2} \mathrm{O} \rightarrow 1.5 \mathrm{O}_{2}+2 \mathrm{ClO}_{3}{ }^{-}+4 \mathrm{Cl}^{-}+12 \mathrm{H}^{+}+6 \mathrm{e} \\
& \mathrm{E}^{\Theta}=1.14 \mathrm{~V}
\end{aligned}
$$

S. Kotowski and B. Busse ${ }^{32}$ studied a chlor-alkali membrane cell system, and found that only 20 to $60 \%$ of oxygen is evolved by Reactions 7 and 8 whereas the rest is produced by the oxidation of water and the following reaction: ${ }^{23}$

$$
\mathrm{HClO}+\mathrm{H}_{2} \mathrm{O} \rightarrow \mathrm{O}_{2}+\mathrm{Cl}^{-}+3 \mathrm{H}^{+}+2 \mathrm{e} \quad \mathrm{E}^{\Theta}=0.97 \mathrm{~V}
$$

Similar assumptions were made by J. E. Colman and B. V. Tilak, ${ }^{6}$ K. L. Hardee and L. K. Mitchell, ${ }^{33}$ Byrne et al. ${ }^{34}$ and R.K.B. Karlsson and A. Cornell. ${ }^{35}$

The anodic current losses may also be induced by the anodic oxidation of water and $\mathrm{OH}^{-}$ions:

$$
\begin{array}{cc}
2 \mathrm{H}_{2} \mathrm{O} \rightarrow \mathrm{O}_{2}+4 \mathrm{H}^{+}+4 \mathrm{e} & \mathrm{E}^{\Theta}=1.23 \mathrm{~V} \\
2 \mathrm{OH}^{-} \rightarrow \frac{1}{2} \mathrm{O}_{2}+\mathrm{H}_{2} \mathrm{O}+2 \mathrm{e} & \mathrm{E}^{\mathrm{O}}=0.40 \mathrm{~V}
\end{array}
$$

The losses induced by Reactions 10 and 11 become substantial at low chloride concentrations and at low anode potentials. ${ }^{8,10,12,13,31,35-38}$ The composition of the active coating makes a significant contribution to these losses. ${ }^{8,37}$ Under industrial chlorate production conditions, during the electrolysis of $\mathrm{NaCl}$ solution at concentrations above $100 \mathrm{~g}$ $\mathrm{dm}^{-3}$, when highly selective DSA anodes are used, the current losses resulting from Reactions 10 and 11 are negligible. ${ }^{10,33,35-37}$

Hydrogen evolution is the primary reaction at the cathode:

$$
2 \mathrm{H}^{+}+2 \mathrm{e} \rightarrow \mathrm{H}_{2} \quad \mathrm{E}=0.00 \mathrm{~V}
$$

$$
2 \mathrm{H}_{2} \mathrm{O}+2 \mathrm{e} \rightarrow \mathrm{H}_{2}+2 \mathrm{OH}^{-} \quad \mathrm{E}=-0.828
$$

Reaction 12 is dominant at low current densities $\left(\mathrm{j}<0.1 \mathrm{kAm}^{-2}\right)$, whereas under chlorate production conditions $\left(1.5 \mathrm{kAm}^{-2}<\mathrm{j}<4.5\right.$ $\mathrm{kAm}^{-2}$ ) hydrogen is mostly evolved from water (Reaction 13). The intensity of Reaction 12 is dependent on factors such as mass transport and buffer capacity of the electrolyte. ${ }^{38,39}$

Apart from Reactions 12 and 13, the reduction of hypochlorite and chlorates may also occur at the cathode: ${ }^{23}$

$$
\mathrm{ClO}^{-}+\mathrm{H}_{2} \mathrm{O}+2 \mathrm{e} \rightarrow \mathrm{Cl}^{-}+2 \mathrm{OH}^{-} \quad \mathrm{E}^{\Theta}=0.89 \mathrm{~V}
$$

$$
\mathrm{ClO}_{3}{ }^{-}+3 \mathrm{H}_{2} \mathrm{O}+6 \mathrm{e} \rightarrow \mathrm{Cl}^{-}+6 \mathrm{OH}^{-} \quad \mathrm{E}^{\Theta}=0.63 \mathrm{~V}
$$

In the absence of chromium(VI) in the solution, these two reactions are the main reason for the current efficiency loss at the cathode. Reaction 14 is controlled by mass transport. ${ }^{31-40}$ Reaction 15 is kinetically controlled, and its rate depends on the catalytic properties of the cathode material. ${ }^{41}$ The addition of 2 to $5 \mathrm{~g} \mathrm{dm}^{-3} \mathrm{Na}_{2} \mathrm{Cr}_{2} \mathrm{O}_{7}$ to the solution leads to the formation of a protective film on steel or titanium cathodes, which prevents Reactions 14 and $15 .{ }^{1-7,15-17,41-48}$ This film also prevents the cathodic reduction of dissolved oxygen ${ }^{42,49}$ and nitrate and nitrite ions. ${ }^{50}$

During the electrolysis, chromium(VI) is reduced to $\mathrm{Cr}$ (III) at the cathode to form a chromium(III) hydroxide film. The film is thin, thinner than $10 \mathrm{~nm}$, and contains a high amount of water. ${ }^{43}$

In the chlorate cell, low-carbon steel is the most common cathode material. Although the electrode is cathodically protected during the operation, its corrosion cannot be overlooked during operational stops. The chromium(III) hydroxide film protects the steel from corrosion by acting as a barrier to oxidants such as oxygen and hypochlorite..$^{51,52}$
The addition of chromium (VI) to the solution also affects the anode process. ${ }^{53-55}$ Chromium(VI) species can adsorb onto the active sites of DSA anodes, thus increasing the anodic potential and thereby promoting the oxygen evolution reaction and increasing the rate of corrosion of the active coating. ${ }^{53-55}$

Through a buffering effect, chromium(VI) reduces the acidity near the anodic surface. Reactions where oxygen is formed from hypochlorite ions depend on $\mathrm{pH}$, which determines the ratio of the reactants $\mathrm{HClO} / \mathrm{ClO}^{-} .{ }^{56}$

The species resulting from the dissolution of $\mathrm{Na}_{2} \mathrm{Cr}_{2} \mathrm{O}_{7}$ in the solution can catalyze the disproportionation reaction (Reaction 4) and thus decrease the steady-state concentration of hypochlorous acid and hypochlorite. ${ }^{23,57}$ As the anodic oxygen formation (Reactions 7 and 8 ) is proportional to the concentration of hypochlorite, an indirect effect of chromate addition is that it lowers the oxygen production through this mechanism. ${ }^{23} \mathrm{~J}$. Wanngård and M. Wildlock ${ }^{23}$ showed that the rate of disporportionation can be described as an uncatalyzed third-order reaction with respect to hypochlorite species and a parallel chromate-catalyzed reaction of apparent reaction order 2.2. The kinetic effect of the chromate species also lowers the optimum reaction $\mathrm{pH}$ below that of the uncatalyzed reaction. These authors also showed that hypochlorite consuming reactions such as anodic and homogeneous oxygen formation as well as cathodic reduction and desorption of chlorine species in the cell gas have no significant effect on the steady-state concentration of hypochlorite in the chlorate cell. ${ }^{23}$

Salts and oxides of some metals $\mathrm{Mn}(\mathrm{II}), \mathrm{F}(\mathrm{III}), \mathrm{Co}(\mathrm{II}), \mathrm{Ni}(\mathrm{II})$, $\mathrm{Cu}$ (II) catalyze the decomposition of hypochlorous acid and hypochlorite (Reactions 5 and 6) ${ }^{58-60} \mathrm{~S}$. Sandin et al. ${ }^{22}$ determined that the addition of $10 \mu \mathrm{mol} \mathrm{dm}{ }^{-3} \mathrm{FeCl}_{3}, \mathrm{Fe}_{3} \mathrm{O}_{4}, \mathrm{CeCl}_{3}, \mathrm{Na}_{2} \mathrm{Cr}_{2} \mathrm{O}_{7}, \mathrm{Na}_{2} \mathrm{MoO}_{4}$, $\mathrm{RuCl}_{3}$ and $\mathrm{RuO}_{2}, 100 \mathrm{ppm}$ of $\mathrm{AgCl}$ and $9 \mathrm{ppm}$ of $\mathrm{Al}_{2} \mathrm{O}_{3}$ to dilute $\mathrm{NaOCl}$ solutions did not catalyze the decomposition of hypochlorite to oxygen or chlorate. However, the addition of $10 \mu \mathrm{mol} \mathrm{dm}{ }^{-3}$ of $\mathrm{CoCl}_{3}$ or $\mathrm{IrCl}_{3}$ catalyzes Reactions 5 and 6 . Under industrial chlorate production conditions, the content of heavy metal salts in the electrolyte is low and, hence, their effect on the rate of hypochlorite decomposition is negligible. ${ }^{1-7}$

The addition of chromium(VI) to the solution for the electrolytic production of chlorate ensures a buffering effect. The $\mathrm{HCrO}_{4}{ }^{-} / \mathrm{CrO}_{4}{ }^{2-}$ system has its maximal buffer capacity in the $\mathrm{pH}$ region 6.0-6.5, which coincides very well with the optimal $\mathrm{pH}$ of the chlorate formation Reaction 4. In the chromium(VI) solution, the following equilibria are established: ${ }^{61-63}$

$$
\mathrm{Cr}_{2} \mathrm{O}_{7}{ }^{2-}+\mathrm{H}_{2} \mathrm{O} \leftrightarrow 2 \mathrm{HCrO}_{4}{ }^{-} \quad \mathrm{K}_{1}=10^{-2} \mathrm{~mol} \mathrm{dm}^{-3}
$$

$$
\mathrm{HCrO}_{4}{ }^{-} \leftrightarrow \mathrm{CrO}_{4}{ }^{2-}+\mathrm{H}^{+} \quad \mathrm{K}_{2}=5.01 \cdot 10^{-6} \mathrm{~mol} \mathrm{dm}^{-3}
$$

During the electrolysis of the solution without chromium(VI) in the chlorate cell, in the vicinity of the anode, due to chlorine hydrolysis (Reaction 2), the solution $\mathrm{pH}$ can be lower than 1.0. ${ }^{39}$ In such an acidic environment, the reduction of chlorate by chloride can result in chlorine dioxide. ${ }^{6,64}$ In the presence of chromium(VI), owing to the buffering effect, chlorine dioxide is not formed. ${ }^{39}$

Previous considerations have shown that the effect of chromium(VI) addition on the kinetics and mechanism of homogeneous and electrode reactions taking place in the chlorate process has not been elucidated yet. Therefore, the objective of this study was to examine the catalytic effect of chromium(VI) addition on the kinetics and mechanism of disproportionation of hypochlorous acid and hypochlorite into chlorate.

\section{Experimental}

The rate of disproportionation of hypochlorous acid and hypochlorite was determined in the solutions: $110 \mathrm{~g} \mathrm{dm}^{-3} \mathrm{NaCl} ; 540 \mathrm{~g} \mathrm{dm}^{-3}$ $\mathrm{NaClO}_{3}$ and $\left.\mathrm{C}\left(\mathrm{Na}_{2} \mathrm{Cr}_{2} \mathrm{O}_{7}\right)=\mathrm{a}\right) \cdots 0.00 \mathrm{~mol} \mathrm{dm} \mathrm{dm}^{-3}$; b) $\cdots 0.00375$ $\mathrm{mol} \mathrm{dm}{ }^{-3}\left(1.0 \mathrm{~g} \mathrm{dm}^{-3}\right)$; c) $\cdots 0.011357 \mathrm{~mol} \mathrm{dm}-3\left(3.0 \mathrm{~g} \mathrm{dm}^{-3}\right)$; d) $\cdots 0.01895 \mathrm{~mol} \mathrm{dm}^{-3}\left(5.0 \mathrm{~g} \mathrm{dm}^{-3}\right)$ and e $) \cdots 0.02650 \mathrm{~mol} \mathrm{dm}^{-3}(7.0 \mathrm{~g}$ 


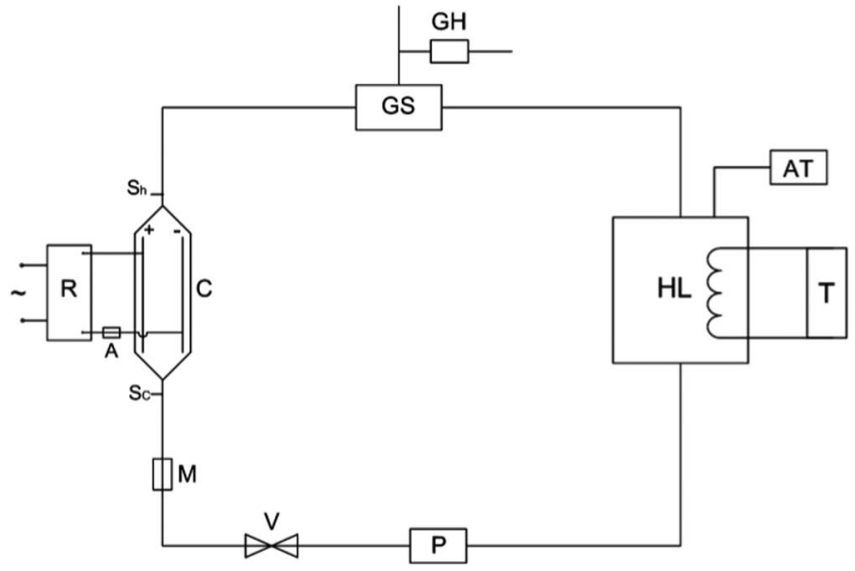

Figure 1. Chlorate apparatus: c . electrochemical cell; GS . . gas/liquid separator; GH . . gas analyzer; HL . holding tank; T . thermostat; P . . pump; V . f flow check valve; M . f flow meter; R . rectifier; A . ammeter, $\mathrm{Sc}$ and $\mathrm{Sh}$. s sampling valves, and AT * automatic titrator of $\mathrm{NaOH}$ or $\mathrm{HCl}$ solution.

$\mathrm{dm}^{-3}$ ). Temporal changes in the concentration of hypochlorous acid and hypochlorite, $\mathrm{C}\left(\mathrm{HClO}+\mathrm{ClO}^{-}\right)$, were monitored.

A $3.0 \mathrm{dm}^{3}$ glass container holding the solutions was placed in the thermostat. The temperature of the solutions was $70 \pm 0.5^{\circ} \mathrm{C}$, and $\mathrm{pH}$ values were: a) $\cdots 6.0 \pm 0.02$; b) $\cdots 6.4 \pm 0.002$ and c) $\cdots 7.0$ \pm 0.02 . The desired $\mathrm{pH}$ values were maintained by the addition of dissolved $\mathrm{NaOH}$ or $\mathrm{HCl}$ using an automatic titrator, and by intensive mixing using a magnetic stirrer. Solution $\mathrm{pH}$ was measured by a WTW $\mathrm{pH}-340 \mathrm{pH}$ meter.

The tested solutions of the desired concentration of hypochlorous acid and hypochlorite, $\mathrm{C}\left(\mathrm{HClO}+\mathrm{ClO}^{-}\right)$, were obtained in the apparatus composed of an electrochemical cell, a gas/liquid separator, a holding tank, a thermostat, a pump, a flow check valve, and an automatic titrator of $\mathrm{NaOH}$ or $\mathrm{HCl}$ solution (Fig. 1).

The cell case, gas separator and the holding tank were made of Plexiglas and connected by polypropylene tubing. The holding tank contained $12.0 \mathrm{dm}^{3}$ of the solution. The total volume of the solution in the apparatus was $13.5 \mathrm{dm}^{3}$. The anode used was a DSA plate with a surface area of $84.1 \mathrm{~cm}^{2}$ and an active coating containing $40 \mathrm{~mol} \%$ $\mathrm{RuO}_{2}$ and $60 \mathrm{~mol} \% \mathrm{TiO}_{2}$. At a distance of $0.3 \mathrm{~cm}$, a titanium cathode plate was placed parallel to the anode. For experimental purposes, in the absence of $\mathrm{Na}_{2} \mathrm{Cr}_{2} \mathrm{O}_{7}$, a titanium cathode covered with a highly selective $\mathrm{Cr}-\mathrm{MoO}_{2}$ coating, where no reduction of $\mathrm{HClO}$ and $\mathrm{ClO}^{-}$ occurred, was used. ${ }^{65}$ Both electrodes were $0.3 \mathrm{~cm}$ in thickness. The temperature of the solutions in the apparatus was $70 \pm 0.5^{\circ} \mathrm{C}$. The desired $\mathrm{pH}$ of the solutions was adjusted by the addition of $\mathrm{NaOH}$ or $\mathrm{HCl}$ using an automatic titrator. The compositions of the solutions before the electrolysis in the apparatus were as follows: $110 \mathrm{~g}$ $\mathrm{dm}^{-3} \mathrm{NaCl} ; 540 \mathrm{~g} \mathrm{dm}^{-3} \mathrm{NaClO}_{3}$ and $\left.\mathrm{C}\left(\mathrm{Na}_{2} \mathrm{Cr}_{2} \mathrm{O}_{7}\right)=\mathrm{a}\right) \cdots 0.00 \mathrm{~mol}$ $\mathrm{dm}^{-3}$; b) $\cdots 0.00378 \mathrm{~mol} \mathrm{dm}{ }^{-3}$; c) $\cdots 0.011357 \mathrm{~mol} \mathrm{dm}^{-3}$; d) $\cdots$ $0.01895 \mathrm{~mol} \mathrm{dm}^{-3}$ and e) $\cdots 0.02650 \mathrm{~mol} \mathrm{dm}^{-3}$. The solutions were prepared from reagent-grade chemicals and triple-distilled water. The required concentrations of hypochlorous acid and hypochlorite were obtained by electrolysis at a current density of $\mathrm{j}=3 \mathrm{kAm}^{-2}$. The solution was taken from the apparatus (Fig. 1.) at a sampling point located in front of the cell, and transferred through the tube into a separate glass container. Samples for the analysis of the temporal dependence of hypochlorite and hypochlorous acid concentrations (Fig. 2.) were sampled from the separate glass container, whereas samples for the analysis of the $\mathrm{pH}$ dependence of steady-state concentrations of hypochlorous acid and hypochlorite for different concentrations of chromium(VI) were taken at the point in front of the cell apparatus (Fig. 1). Gas composition during hypochlorite decomposition was not analyzed. At the initial time interval, there was a relatively rapid decrease in the concentration of $\left(\mathrm{HClO}+\mathrm{ClO}^{-}\right)$due to dispropor- tionation, and a negligible rate of decomposition of hypochlorous acid and hypochlorite into oxygen and chloride (Reaction 5). Therefore, in this case, it was extremely difficult to establish a precise dependence of $\mathrm{O}_{2}$ content on $\mathrm{C}\left(\mathrm{HClO}+\mathrm{ClO}^{-}\right)$.

The sum of hypochlorous acid and hypochlorite concentrations, $\mathrm{C}\left(\mathrm{HClO}+\mathrm{ClO}^{-}\right)$, was determined by potentiometric titration with $\mathrm{As}_{2} \mathrm{O}_{3}$ solution, and that of chlorate concentration by titration with $\mathrm{KBrO}_{3}$ solution. ${ }^{7}$ The concentration of $\mathrm{NaClO}_{3}$ was potentiometrically measured immediately after a steady state was established, and then after about $15 \% \mathrm{NaCl}$ was converted. The current efficiency for chlorate formation was mostly determined based on the composition of the output gas mixture. ${ }^{7,29}$ The composition of the mixture was determined by gas chromatography. Measurements were made after reaching a steady state. Three measurements were made at an interval of 90 minutes, and the mean was determined thereafter. In cases involving potentiometric measurements of the increment of $\mathrm{NaClO}_{3}$ concentration during a given time interval, gas analysis was performed six times. The data on the current efficiency for chlorate generation determined using the composition of the output gas mixture were in good agreement with the results obtained by measuring the increment of chlorate concentration $( \pm 0.6 \%)$.

\section{Results and Discussion}

Studies ${ }^{22,23}$ have shown that, in the absence of $\mathrm{Na}_{2} \mathrm{Cr}_{2} \mathrm{O}_{7}$, disproportionation (Reaction 4) is a third-order reaction of the form:

$$
-\frac{d C\left(\mathrm{HClO}+\mathrm{ClO}^{-}\right)}{d t}=\mathrm{k}_{1} \mathrm{C}^{2}(\mathrm{HClO}) \cdot \mathrm{C}\left(\mathrm{ClO}^{-}\right)
$$

The value of the constant $\mathrm{k}_{1}$ was found to increase exponentially with increasing temperature of the solution and increasing concentrations of $\mathrm{NaCl}$ and $\mathrm{NaClO}_{3} \cdot{ }^{18-23}$ Table I. provides $\mathrm{k}_{1}$ values obtained by J. Wanngård and M. Wildlock. ${ }^{23}$

In the presence of chromium(VI), the same authors ${ }^{23}$ showed that the rate of chlorate formation can be described as an uncatalyzed third-order reaction with respect to hypochlorite species and a parallel chromate-catalyzed reaction with the partial orders $1.0 ; 1.7$ and 0.5 with respect to $\mathrm{CrO}_{4}{ }^{2-}, \mathrm{HClO}$ and $\mathrm{HClO}+\mathrm{ClO}^{-}$, respectively.

In the present experiment, the composition of the solution used in evaluating the effect of chromium(VI) on the kinetics of disproportionation of hypochlorous acid and hypochlorite was similar to the composition of the solution used in the electrolytic chlorate process. The composition of the starting solution was: $110 \mathrm{~g} \mathrm{dm}^{-3} \mathrm{NaCl}$; $540 \mathrm{~g} \mathrm{dm}^{-3} \mathrm{NaClO}_{3}$ and $\left.\left.\mathrm{C}\left(\mathrm{Na}_{2} \mathrm{Cr}_{2} \mathrm{O}_{7}\right)=\mathrm{a}\right) \cdots 0.00 \mathrm{~mol} \mathrm{dm}{ }^{-3} ; \mathrm{b}\right)$ . $0.00378 \mathrm{~mol} \mathrm{dm}^{-3}$; c) . $0.011357 \mathrm{~mol} \mathrm{dm}^{-3}$; d) . $0.01895 \mathrm{~mol}$ $\mathrm{dm}^{-3}$ and e) $\cdots 0.02650 \mathrm{~mol} \mathrm{dm}^{-3}$.

The dependences of $\mathrm{C}\left(\mathrm{HClO}+\mathrm{ClO}^{-}\right)$on time, $\mathrm{t}$, solution $\mathrm{pH}$ and $\mathrm{Na}_{2} \mathrm{Cr}_{2} \mathrm{O}_{7}$ concentration, $\mathrm{C}\left(\mathrm{Na}_{2} \mathrm{Cr}_{2} \mathrm{O}_{7}\right)$, were recorded (Fig. 2). The diagrams in Fig. 2 show that the increase in chromium(VI) concentration, $\mathrm{C}\left(\mathrm{Na}_{2} \mathrm{Cr}_{2} \mathrm{O}_{7}\right)$, results in an increase in the rate of disproportionation. Using the diagrams presented in Fig. 2, for $\mathrm{C}\left(\mathrm{HClO}+\mathrm{ClO}^{-}\right)$ $0.015 \mathrm{~mol} \mathrm{dm}^{-3}, 0.02 \mathrm{~mol} \mathrm{dm}^{-3}, 0.025 \mathrm{~mol} \mathrm{dm}^{-3}$ and $0.03 \mathrm{~mol}$ $\mathrm{dm}^{-3}$, the values of the parameters: $-\frac{d \mathrm{C}\left(\mathrm{HClO}+\mathrm{ClO}^{-}\right)}{d t}, \frac{1}{2 \mathrm{C}^{2}\left(\mathrm{HClO}+\mathrm{ClO}^{-}\right)}$ and $\mathrm{C}^{3}\left(\mathrm{HClO}+\mathrm{ClO}^{-}\right)$were determined for the diagrams plotted in Fig. 3 - Fig. 6. The rates of disproportionation, - $\frac{d \mathrm{C}\left(\mathrm{HClO}+\mathrm{ClO}^{-}\right)}{d t}$, were determined by the slopes of the tangent lines $-\frac{\Delta \mathrm{C}\left(\mathrm{HClO}+\mathrm{ClO}^{-}\right)}{\Delta t}$ to the curves in Figs. $2 \mathrm{a}, 2 \mathrm{~b}$ and $2 \mathrm{c}$. Figure 3 presents the rate of disproportionation of hypochlorus acid and hypochlorite as a function of solution $\mathrm{pH}$, hypochlorous acid and hypochlorite concentration, $\mathrm{C}\left(\mathrm{HClO}+\mathrm{ClO}^{-}\right)$, and chromium(VI) concentration, $\mathrm{C}\left(\mathrm{Na}_{2} \mathrm{Cr}_{2} \mathrm{O}_{7}\right)$.

Figure 4 presents the rate of disproportionation - $\frac{d \mathrm{C}\left(\mathrm{HClO}+\mathrm{ClO}^{-}\right)}{d t}$ as a function of the third power of hypochlorous acid and hypochlorite concentration, $\mathrm{C}^{3}\left(\mathrm{HClO}+\mathrm{ClO}^{-}\right)$, at constant $\mathrm{pH}$ values.

The diagrams in Fig. 4 show that the rate of disproportionation in both the absence and presence of chromium(VI), at a constant $\mathrm{pH}$, increases linearly with the third power of the concentration of hypochlorus acid and hypochlorite. 
a)

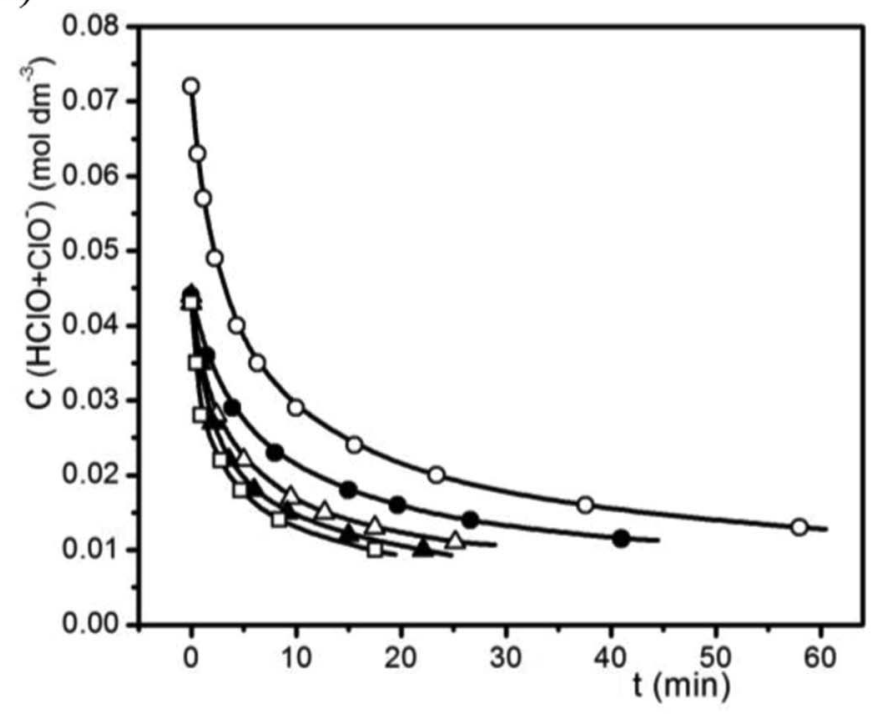

b)

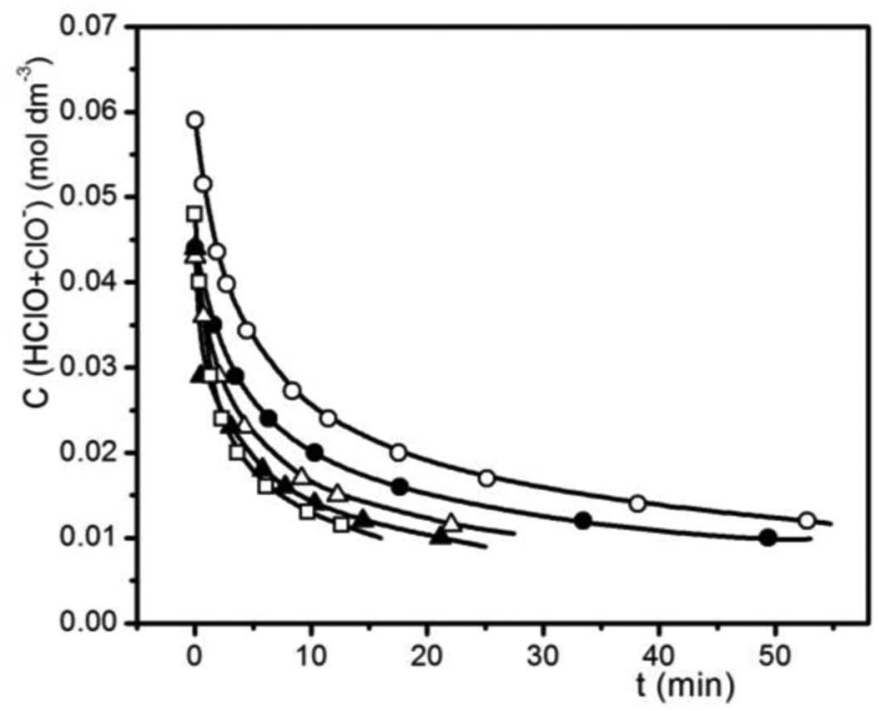

c)

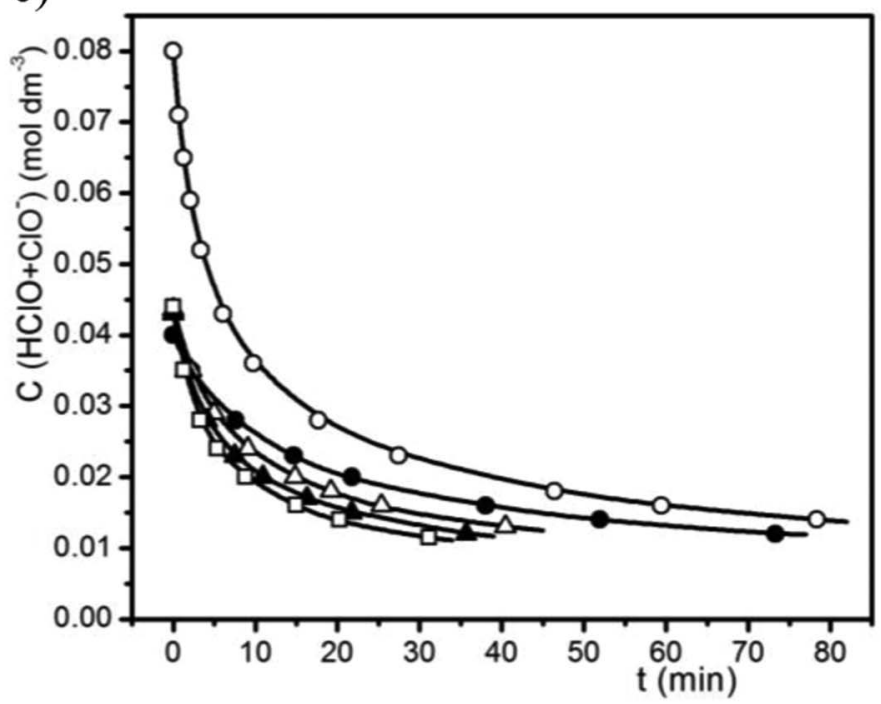

Figure 2. The concentration of hypochlorous acid and hypochlorite, $\mathrm{C}\left(\mathrm{HClO}+\mathrm{ClO}^{-}\right)$, as a function of time and chromium $(\mathrm{VI})$ concentration, $\mathrm{C}\left(\mathrm{Na}_{2} \mathrm{Cr}_{2} \mathrm{O}_{7}\right)$ : $\circ$. . $0.00 \mathrm{~mol} \mathrm{dm}^{-3} \mathrm{Na}_{2} \mathrm{Cr}_{2} \mathrm{O}_{7} ; \bullet 0.00378 \mathrm{~mol} \mathrm{dm}^{-3} \mathrm{Na}_{2} \mathrm{Cr}_{2} \mathrm{O}_{7} ; \Delta \ldots 0.011357 \mathrm{~mol} \mathrm{dm}^{-3} \mathrm{Na}_{2} \mathrm{Cr}_{2} \mathrm{O}_{7} ; \boldsymbol{\Delta} \cdots 0.01895 \mathrm{~mol} \mathrm{dm}^{-3} \mathrm{Na}_{2} \mathrm{Cr}_{2} \mathrm{O}_{7} ;$ and $^{-} \quad \ldots 0.02650$ mol dm ${ }^{-3} \mathrm{Na}_{2} \mathrm{Cr}_{2} \mathrm{O}_{7}$ at a) $\left.\mathrm{pH}=6.0 ; \mathrm{b}\right) \mathrm{pH}=6.4$ and c) $\mathrm{pH}=7.0 .\left(\mathrm{C}(\mathrm{NaCl})=110 \mathrm{~g} \mathrm{dm}^{-3} ; \mathrm{C}\left(\mathrm{NaClO}_{3}\right)=540 \mathrm{~g} \mathrm{dm}^{-3}, \mathrm{t}=70^{\circ} \mathrm{C}\right)$.

Fig. 5 illustrates the dependence of the rate of disproportionation on the concentration of chromium(VI) at a constant $\mathrm{pH}$ and at the third power of the concentration of hypochlorous acid and hypochlorite.

Using the diagrams in Figs. 3 and 4, it is assumed that disproportionation in both the presence and absence of chromium(VI) is a third-order reaction with respect to hypochlorous acid and hypochlorite, and that the reaction rate constant is dependent on solution $\mathrm{pH}$ and chromium(VI) concentration. Based on this assumption, a unique kinetic expression can be written for the rate of uncatalyzed and cat- alyzed disproportionation reactions:

$$
\frac{-d C\left(\mathrm{HClO}+\mathrm{ClO}^{-}\right)}{d t}=\mathrm{k}_{5} \cdot \mathrm{C}^{2}(\mathrm{HClO}) \cdot \mathrm{C}\left(\mathrm{ClO}^{-}\right)
$$

where $\mathrm{k}_{5}=\mathrm{f}\left(\mathrm{pH}, \mathrm{C}\left(\mathrm{Na}_{2} \mathrm{Cr}_{2} \mathrm{O}_{7}\right)\right)$.

Given the experimental determination of both $\mathrm{pH}$ and the total concentration of hypochlorous acid and hypochlorite, Expression 19 is transformed into an expression which gives the dependence of the disproportionation rate on $\mathrm{C}\left(\mathrm{H}^{+}\right)$and $\mathrm{C}\left(\mathrm{HClO}+\mathrm{ClO}^{-}\right)$. Combining

Table I. Values of the constant $\mathrm{k}_{1}$ depending on solution temperature and composition. ${ }^{23}$

$\mathrm{k}_{1} \mathrm{~mol}^{-2} \mathrm{dm}^{-6} \mathrm{~s}^{-1}$

$6.58 \leq \mathrm{k}_{1} \leq 8.14$

$11.42 \leq \mathrm{k}_{1} \leq 13.58$
Solution composition $\left(\mathrm{g} \mathrm{dm}^{-3}\right)$

$$
\begin{gathered}
528 \leq \mathrm{NaClO}_{3} \leq 623 \\
54 \leq \mathrm{NaCl} \leq 111 \\
223 \leq \mathrm{NaClO}_{3} \leq 604 \\
54 \leq \mathrm{NaCl} \leq 111
\end{gathered}
$$

Temperature $\left({ }^{\circ} \mathrm{C}\right)$ 
a)

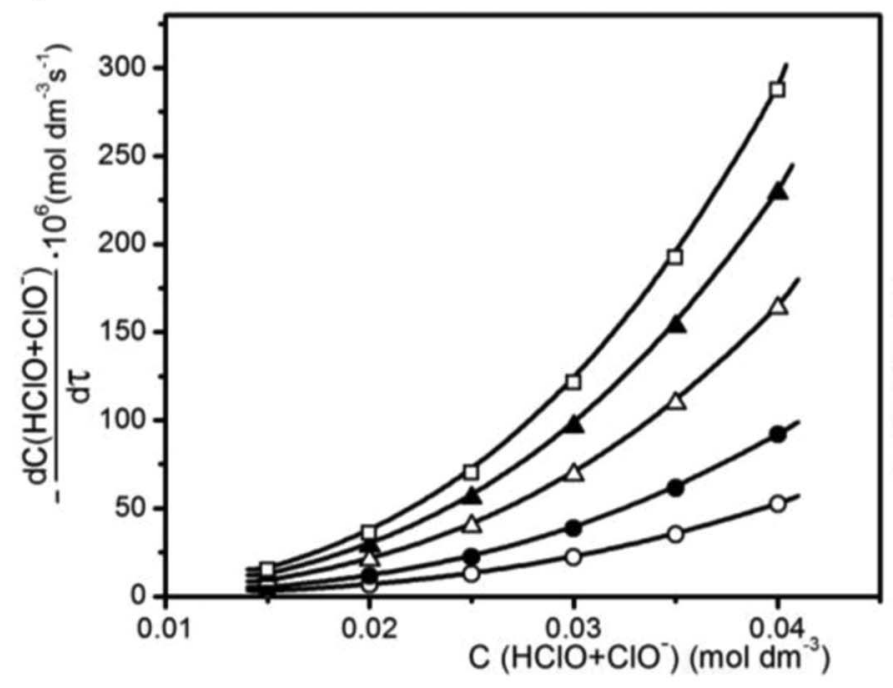

b)

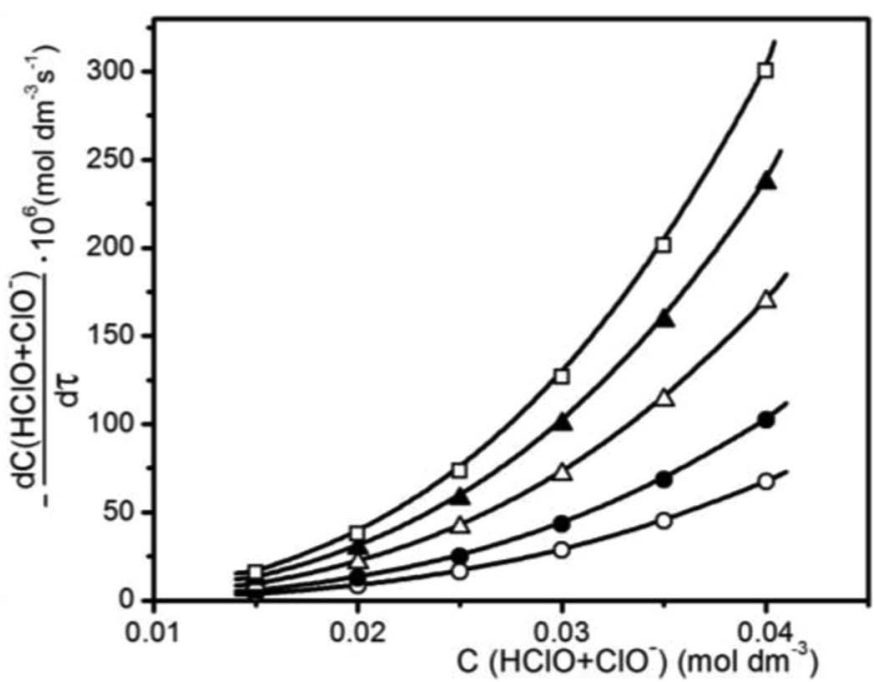

c)

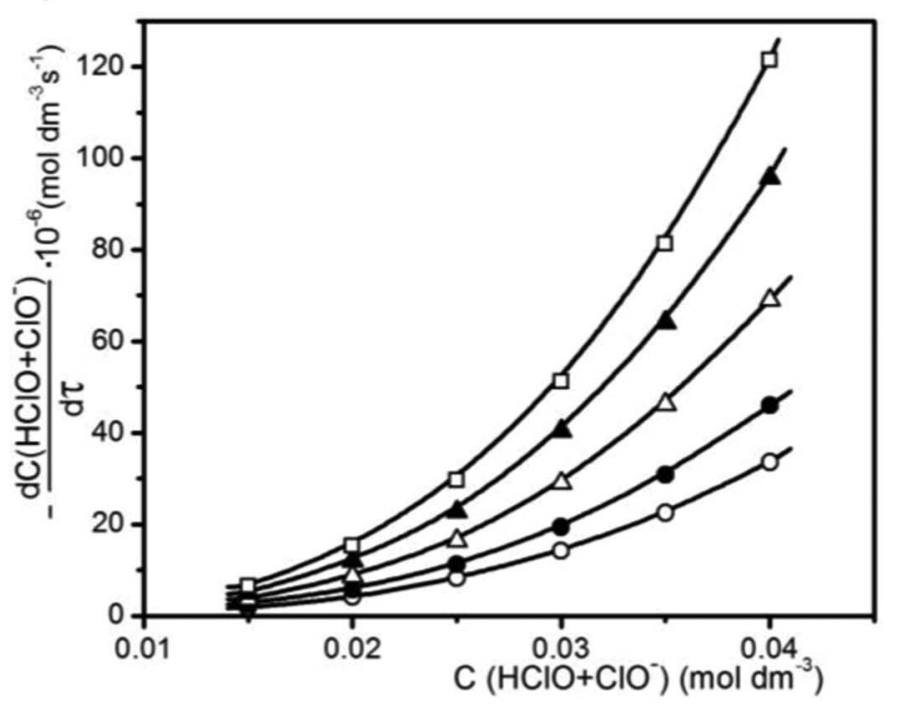

Figure 3. The rate of disproportionation of hypochlorus acid and hypochlorite, $-\frac{d \mathrm{C}\left(\mathrm{HClO}+\mathrm{ClO}^{-}\right)}{d t}$, as a function of the concentration of hypochlorous acid and hypochlorite, $\mathrm{C}\left(\mathrm{HClO}+\mathrm{ClO}^{-}\right)$, for different concentrations of chromium( $\left.\mathrm{VI}\right), \mathrm{C}\left(\mathrm{Na}_{2} \mathrm{Cr}_{2} \mathrm{O}_{7}\right) ; \circ \cdots 0.00 \mathrm{~mol} \mathrm{dm}^{-3} \mathrm{Na}_{2} \mathrm{Cr}_{2} \mathrm{O}_{7} ; \bullet \cdots 0.00378 \mathrm{~mol} \mathrm{dm}^{-3} \mathrm{Na}_{2} \mathrm{Cr}_{2} \mathrm{O}_{7}$; $\Delta \cdots 0.011357 \mathrm{~mol} \mathrm{dm}^{-3} \mathrm{Na}_{2} \mathrm{Cr}_{2} \mathrm{O}_{7} ; \boldsymbol{\Delta} \cdots 0.01895 \mathrm{~mol} \mathrm{dm}^{-3} \mathrm{Na}_{2} \mathrm{Cr}_{2} \mathrm{O}_{7}$; and $\square .0 .02650 \mathrm{~mol} \mathrm{dm}^{-3} \mathrm{Na}_{2} \mathrm{Cr}_{2} \mathrm{O}_{7}$, at different solution $\mathrm{pH}$ values a) $\cdots$ pH $=$ $6.0 ; \mathrm{b}) \cdots \mathrm{pH}=6.4$ and $\mathrm{c}) \cdots \mathrm{pH}=7.0 .\left(\mathrm{C}(\mathrm{NaCl})=110 \mathrm{~g} \mathrm{dm}^{-3} ; \mathrm{C}\left(\mathrm{NaClO}_{3}\right)=540 \mathrm{~g} \mathrm{dm}^{-3}, \mathrm{t}=70^{\circ} \mathrm{C}\right)$.

Equation 19, the equilibrium constant expression for Reaction 3 and the mole balance expression for hypochlorous acid and hypochlorite results in the rate disproportination equation:

$$
\frac{-d C\left(\mathrm{HCl}+\mathrm{ClO}^{-}\right)}{d t}=\mathrm{k}_{5} \frac{K_{3} \cdot \mathrm{C}^{2}\left(\mathrm{H}^{+}\right)}{\left[K_{3}+C\left(H^{+}\right)\right]^{3}} \cdot \mathrm{C}^{3}\left(\mathrm{HClO}+\mathrm{ClO}^{-}\right)
$$

At $\mathrm{pH}=$ const and $\mathrm{C}\left(\mathrm{Na}_{2} \mathrm{Cr}_{2} \mathrm{O}_{7}\right)=$ const, the integral form of Equation 20 is:

$$
\begin{aligned}
& \frac{1}{2 C^{2}\left(\mathrm{HClO}+\mathrm{ClO}^{-}\right)}-\frac{1}{2 \mathrm{C}^{2} \mathrm{o}\left(\mathrm{HClO}+\mathrm{ClO}^{-}\right)} \\
& =\mathrm{k}_{5} \frac{K_{3} \mathrm{C}^{2}\left(\mathrm{H}^{+}\right)}{\left[\mathrm{K}_{3}+\mathrm{C}\left(\mathrm{H}^{+}\right)\right]^{3}} t
\end{aligned}
$$

where: $\mathrm{t}-$ time and $\mathrm{Co}\left(\mathrm{HClO}+\mathrm{ClO}^{-}\right)-$concentration for $\mathrm{t}=0$.
Figure 6 presents $\frac{1}{2 \mathrm{C}^{2}\left(\mathrm{HClO}+\mathrm{ClO}^{-}\right)}$as a function of time, $\mathrm{t}$, for different chromium(VI) concentrations and solution $\mathrm{pH}$ values.

The obtained linear dependences of $\frac{1}{2 \mathrm{C}^{2}\left(\mathrm{HClO} \mathrm{ClO}^{-}\right)}$on $\mathrm{t}$ (Fig. 6) indicate that, at $\mathrm{pH}=$ const and $\mathrm{C}\left(\mathrm{Na}_{2} \mathrm{Cr}_{2} \mathrm{O}_{7}\right)=$ const, in both the absence and presence of chromium (VI), disproportionation is a third-order reaction with respect to hypochlorous acid and hypochlorite.

Based on the slope, $\frac{\Delta \frac{1}{2 \mathrm{C}^{2}\left(\mathrm{HClO}+\mathrm{ClO}^{-}\right)}}{\Delta t}$, of the lines obtained for different chromium(VI) concentrations and solution $\mathrm{pH}$ values, the values of the expression $\mathrm{k}_{5} \frac{K_{3} C^{2}\left(H^{+}\right)}{\left[K_{3}+C\left(H^{+}\right)\right]^{3}}$ were determined, and then the expression was used to calculate the rate constants $\mathrm{k}_{5}$ (Table II).

The values in Table II show that the value of the rate constant, $\mathrm{k}_{5}$, of the disproportionation reaction increases with increasing chromium(VI) concentration and solution acidity. The $\mathrm{pH}$ dependence 
a)

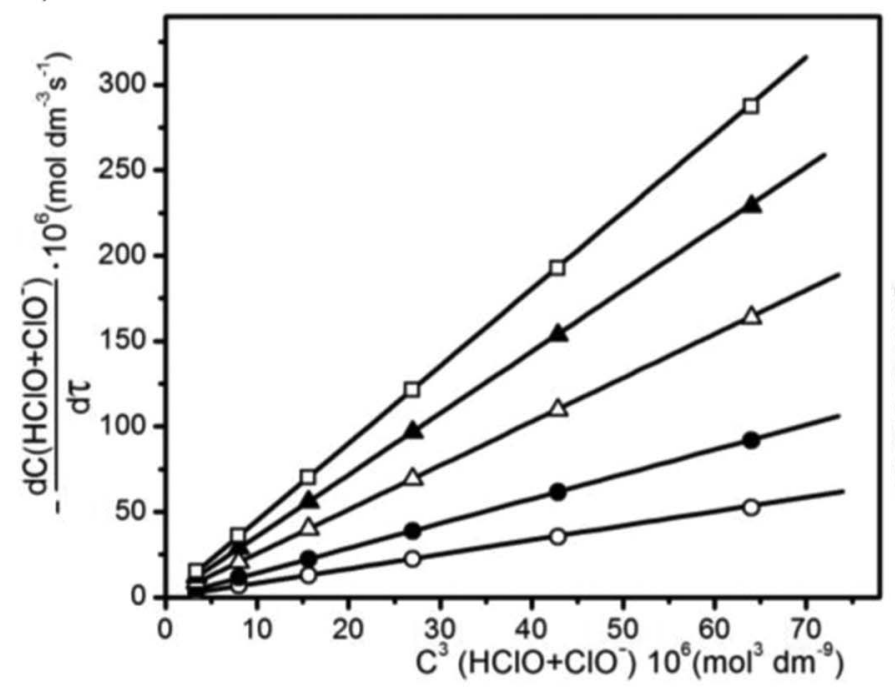

b)

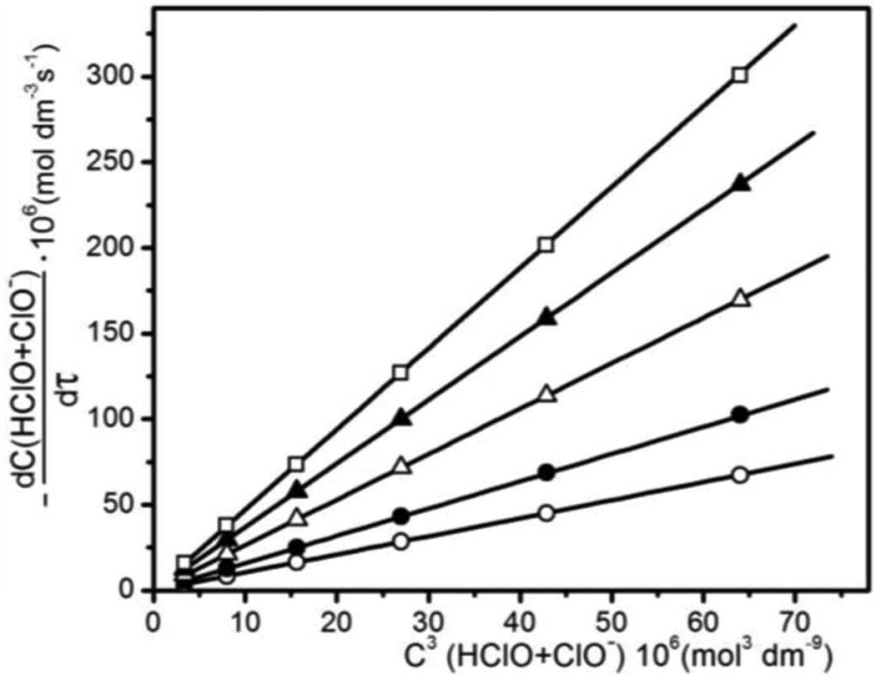

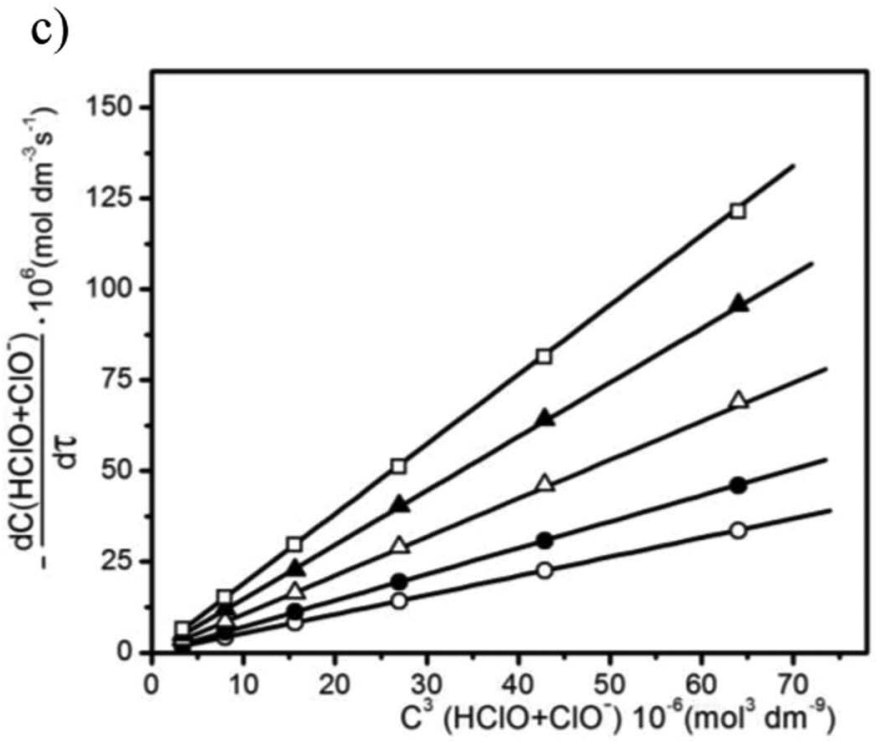

Figure 4. The rate of disproportionation, $-\frac{d \mathrm{C}\left(\mathrm{HClO}_{\mathrm{ClO}} \mathrm{ClO}^{-}\right)}{d t}$, as a function of the third power of hypochlorous acid and hypochlorite concentration, $\mathrm{C}^{3}\left(\mathrm{HClO}+\mathrm{ClO}^{-}\right)$, for different concentrations of chromium(VI): ○ $0.00 \mathrm{~mol} \mathrm{dm}^{-3} \mathrm{Na}_{2} \mathrm{Cr}_{2} \mathrm{O}_{7} ; \bullet \quad 0.00378 \mathrm{~mol} \mathrm{dm}^{-3} \mathrm{Na}_{2} \mathrm{Cr}_{2} \mathrm{O}_{7} ; \Delta \cdots 0.011357 \mathrm{~mol} \mathrm{dm}^{-3} \mathrm{Na}_{2} \mathrm{Cr}_{2} \mathrm{O}_{7} ; \boldsymbol{\Delta}$ $0.01895 \mathrm{~mol} \mathrm{dm}^{-3} \mathrm{Na}_{2} \mathrm{Cr}_{2} \mathrm{O}_{7}$; and $\square \cdots 0.02650 \mathrm{~mol} \mathrm{dm}^{-3} \mathrm{Na}_{2} \mathrm{Cr}_{2} \mathrm{O}_{7}$ at: a) $\left.\cdots \mathrm{pH}=6.0 ; \mathrm{b}\right) \cdots \mathrm{pH}=6.4$ and $\left.\mathrm{c}\right) \cdots \mathrm{pH}=7.0 .(\mathrm{C}(\mathrm{NaCl})=110 \mathrm{~g} \mathrm{dm}-3$ $\left.\mathrm{C}\left(\mathrm{NaClO}_{3}\right)=540 \mathrm{~g} \mathrm{dm}^{-3}, \mathrm{t}=70^{\circ} \mathrm{C}\right)$.

of $\mathrm{k}_{5}$ in the presence of chromium(VI) and no $\mathrm{pH}$ dependence in its absence, and the $\mathrm{pH}$ dependence of the distribution of concentrations of chromium(VI) species $\left(\mathrm{CrO}_{4}{ }^{2-}, \mathrm{Cr}_{2} \mathrm{O}_{7}{ }^{2-}\right.$ and $\left.\mathrm{HCrO}_{4}{ }^{-}\right)$indicate that different chromium(VI) species exhibit different catalytic effects on the disproportionation reaction. Based on this conclusion, it can be assumed that the kinetic expression of the disproportionation reaction in the presence of chromium(VI) in the solution takes the following form:

$$
\begin{aligned}
& \frac{-d C\left(\mathrm{HClO}+\mathrm{ClO}^{-}\right)}{d t}=\mathrm{k}_{1} \mathrm{C}^{2}(\mathrm{HClO}) \cdot \mathrm{C}\left(\mathrm{ClO}^{-}\right) \\
& +\mathrm{k}_{2} \mathrm{C}^{2}(\mathrm{HClO}) \cdot \mathrm{C}\left(\mathrm{ClO}^{-}\right) \cdot \mathrm{C}\left(\mathrm{Cr}_{2} \mathrm{O}_{7}^{2-}\right)
\end{aligned}
$$

Table II. Experimental (E) and calculated (C) values of the rate constant $\mathrm{k}_{5}$ for different concentrations of chromium(VI) and pH values of the solution $\left(\mathrm{C}(\mathrm{NaCl})=110 \mathrm{~g} \mathrm{dm}^{-3} ; \mathrm{C}\left(\mathrm{NaClO}_{3}\right)=540 \mathrm{~g} \mathrm{dm}^{-3}, \mathrm{t}=70^{\circ} \mathrm{C}\right)$.

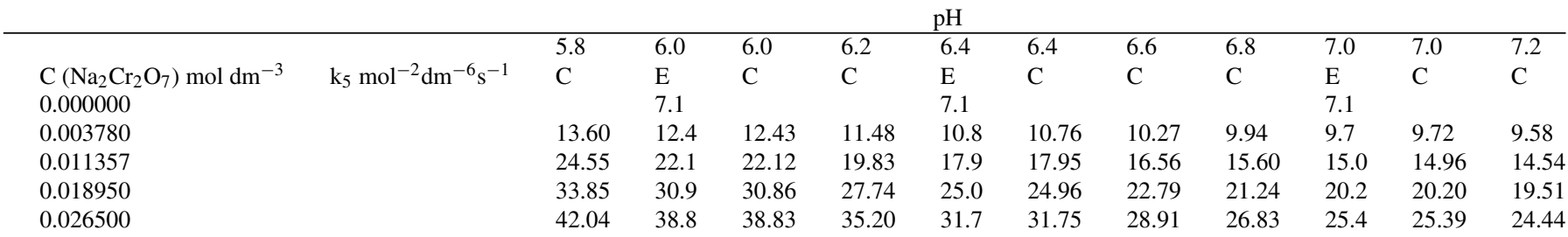


a)

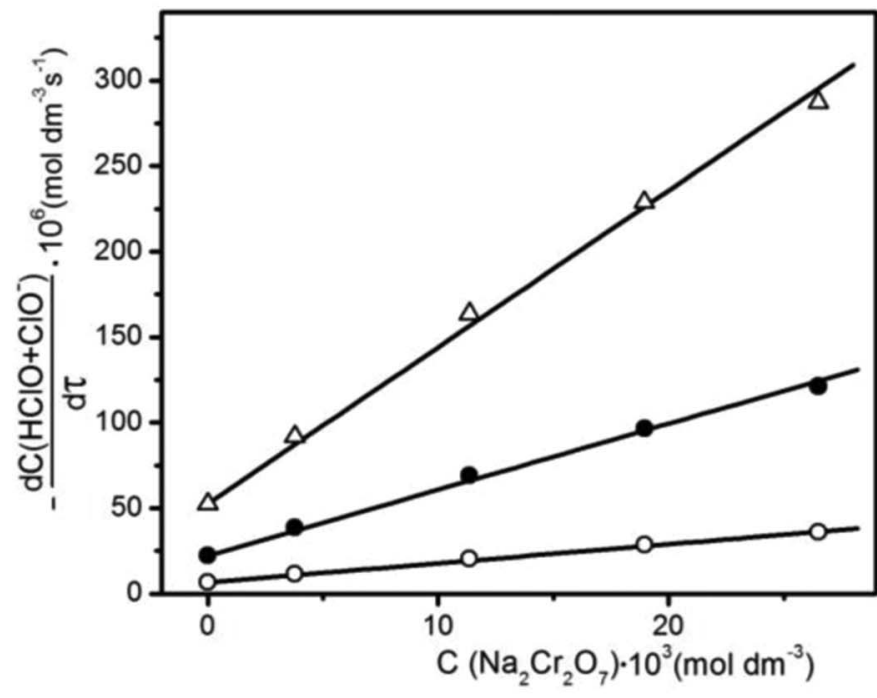

b)

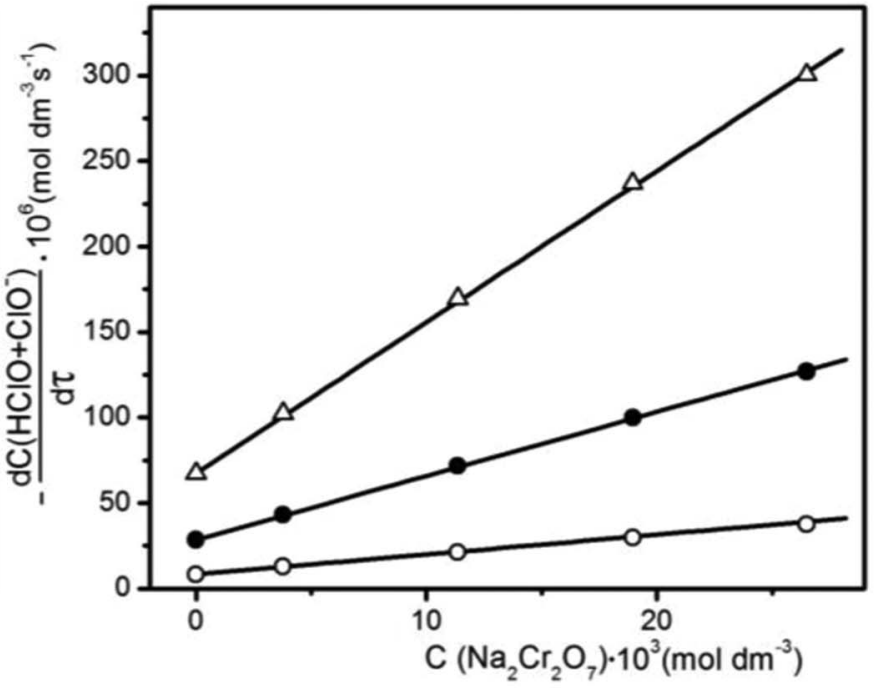

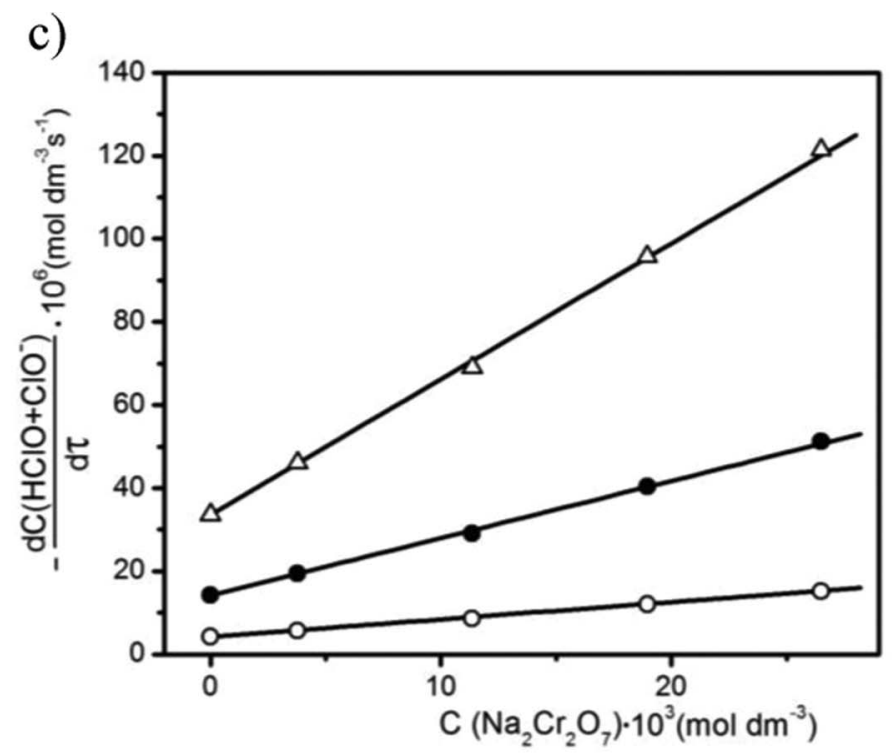

Figure 5. The rate of disproportionation, $-\frac{d \mathrm{C}\left(\mathrm{HClO}_{\mathrm{ClO}} \mathrm{ClO}^{-}\right)}{d t}$, as a function of chromium(VI) concentrationf or different values of the third power of the hypochlorous acid and hypochlorite concentration, $\mathrm{C}^{3}\left(\mathrm{HClO}+\mathrm{ClO}^{-}\right): \circ \cdot 8.0 \cdot 10^{-6} \mathrm{~mol}^{3} \mathrm{dm}^{-9} ; \bullet \cdot 27.0 \cdot 10^{-6} \mathrm{~mol}^{3} \mathrm{dm}^{-9}$ and $\Delta \cdot 64.0 \cdot 10^{-6} \mathrm{~mol}^{3} \mathrm{dm}^{-9}$ at: a) $\cdot \mathrm{pH}^{-}=$

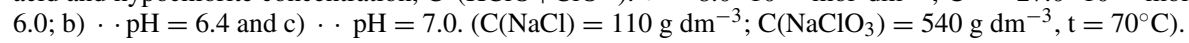

$$
\begin{aligned}
& +\mathrm{k}_{3} \mathrm{C}^{2}(\mathrm{HClO}) \cdot \mathrm{C}\left(\mathrm{ClO}^{-}\right) \cdot \mathrm{C}\left(\mathrm{CrO}_{4}{ }^{2-}\right) \\
& +\mathrm{k}_{4} \mathrm{C}^{2}(\mathrm{HClO}) \cdot \mathrm{C}\left(\mathrm{ClO}^{-}\right) \cdot \mathrm{C}\left(\mathrm{HCrO}_{4}{ }^{-}\right)
\end{aligned}
$$

Rearranging Equation 22 results in:

$$
\begin{gathered}
\frac{-d C\left(\mathrm{HClO}+\mathrm{ClO}^{-}\right)}{d t}=\left[\mathrm{k}_{1}+\mathrm{k}_{2} \cdot \mathrm{C}\left(\mathrm{Cr}_{2} \mathrm{O}_{7}{ }^{2-}\right)+\mathrm{k}_{3} \mathrm{C}\left(\mathrm{CrO}_{4}{ }^{2-}\right)\right. \\
\left.+\mathrm{k}_{4} \mathrm{C}\left(\mathrm{HCrO}_{4}^{-}\right)\right] \cdot \mathrm{C}^{2}(\mathrm{HClO}) \cdot \mathrm{C}\left(\mathrm{ClO}^{-}\right)
\end{gathered}
$$

From Equations 19 and 23, it follows that:

$$
\mathrm{k}_{5}=\mathrm{k}_{1}+\mathrm{k}_{2} \cdot \mathrm{C}\left(\mathrm{Cr}_{2} \mathrm{O}_{7}{ }^{2-}\right)+\mathrm{k}_{3} \mathrm{C}\left(\mathrm{CrO}_{4}{ }^{2-}\right)+\mathrm{k}_{4} \mathrm{C}\left(\mathrm{HCrO}_{4}{ }^{-}\right)
$$

The catalytic effect of some chromium(VI) species $\left(\mathrm{Cr}_{2} \mathrm{O}_{7}{ }^{2-}\right.$, $\mathrm{CrO}_{4}{ }^{2-}$ and $\mathrm{HCrO}_{4}{ }^{-}$) can be expressed by the values of the constants $\mathrm{k}_{2}, \mathrm{k}_{3}$ and $\mathrm{k}_{4}$. These values can be determined by using $\mathrm{k}_{5}$ data (Table II) and concentrations of $\mathrm{Cr}_{2} \mathrm{O}_{7}{ }^{2-}, \mathrm{CrO}_{4}{ }^{2-}$ and $\mathrm{HCrO}_{4}{ }^{-}$.

The concentrations of $\mathrm{Cr}_{2} \mathrm{O}_{7}{ }^{2-}$ species are calculated using the equations obtained by combining the equilibrium constant expression for Reactions 16 and 17 and the mole balance expression for $\mathrm{Cr}_{2} \mathrm{O}_{7}{ }^{2-}$, $\mathrm{CrO}_{4}{ }^{2-}$ and $\mathrm{HCrO}_{4}{ }^{-}$:

$$
\begin{gathered}
\mathrm{C}^{2}\left(\mathrm{Cr}_{2} \mathrm{O}_{7}^{2-}\right)-\left\{\left[\frac{-0.5 \mathrm{~K}_{1} \cdot \mathrm{K}_{2}}{\mathrm{C}\left(\mathrm{H}^{+}\right)}-0.5 \mathrm{~K}_{1}^{1 / 2}\right]^{2}+2 \mathrm{C}\left(\mathrm{Na}_{2} \mathrm{Cr}_{2} \mathrm{O}_{7}\right)\right\} \\
\cdot \mathrm{C}\left(\mathrm{Cr}_{2} \mathrm{O}_{7}^{2-}\right)+\mathrm{C}^{2}\left(\mathrm{Na}_{2} \mathrm{Cr}_{2} \mathrm{O}_{7}\right)=0
\end{gathered}
$$

Solving the quadratic Equation 25 gives the expression for the concentration of $\mathrm{Cr}_{2} \mathrm{O}_{7}{ }^{2-}$ ions:

$$
C\left(\mathrm{Cr}_{2} \mathrm{O}_{7}^{2-}\right)=\frac{-\mathrm{B} \pm\left[\mathrm{B}^{2}-4 \mathrm{C}^{2}\left(\mathrm{Na}_{2} \mathrm{Cr}_{2} \mathrm{O}_{7}\right)\right]^{1 / 2}}{2}
$$

where:

$$
\mathrm{B}=\left[\frac{-0.5 K_{1}^{1 / 2} K_{2}}{C\left(H^{+}\right)}-0.5 K_{1}^{1 / 2}\right]^{2}+2 \mathrm{C}\left(\mathrm{Na}_{2} \mathrm{Cr}_{2} \mathrm{O}_{7}\right)
$$


a)

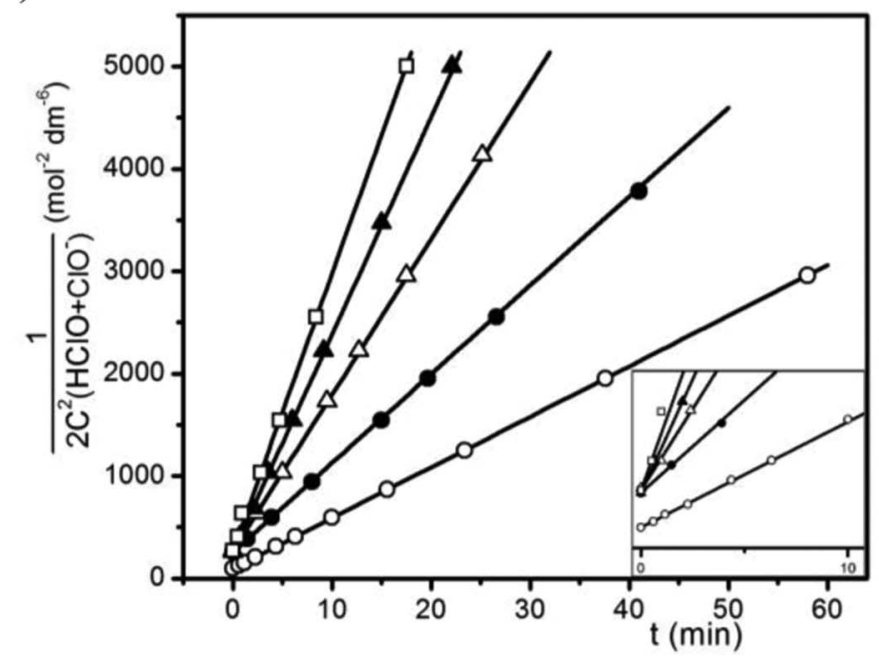

b)

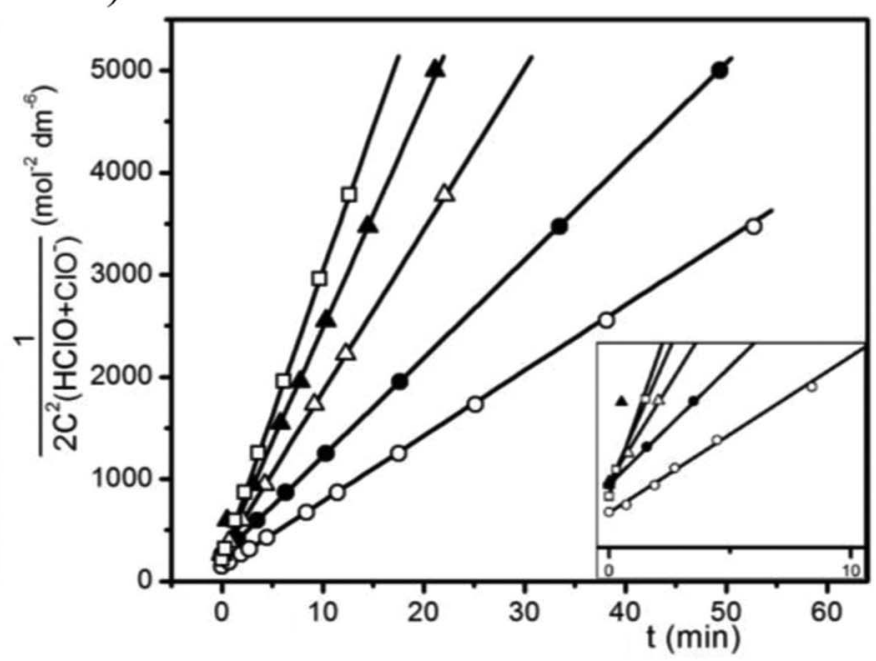

c)

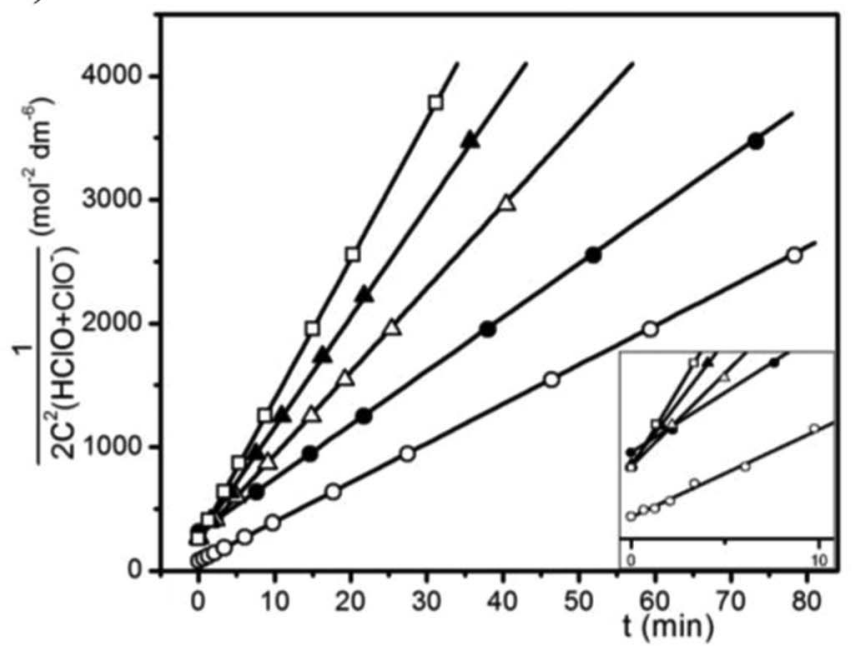

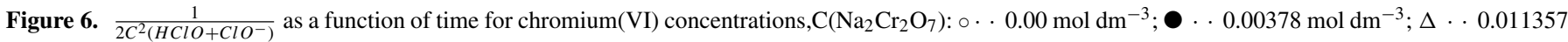
$\mathrm{mol} \mathrm{dm}{ }^{-3} ; \boldsymbol{\Lambda} \cdots 0.01895 \mathrm{~mol} \mathrm{dm}{ }^{-3} ;$ and $\square \cdots 0.02650 \mathrm{~mol} \mathrm{dm}^{-3}$ at: a) $\left.\cdots \mathrm{pH}=6.0 ; \mathrm{b}\right) \cdots \mathrm{pH}=6.4$ and c) $\cdots \mathrm{pH}=7.0 .\left(\mathrm{C}(\mathrm{NaCl})=110 \mathrm{~g} \mathrm{dm}{ }^{-3} ; \mathrm{C}\left(\mathrm{NaClO}_{3}\right)\right.$ $\left.=540 \mathrm{~g} \mathrm{dm}^{-3}, \mathrm{t}=70^{\circ} \mathrm{C}\right)$. The lower right corner contains inserts for the data, $\frac{1}{2 \mathrm{C}^{2}\left(\mathrm{CClO}_{\mathrm{ClO}}^{-)}\right)}$, at short times.

Combining the equilibrium constant expressions for Reaction 16 and 17 yields expressions for $\mathrm{C}\left(\mathrm{HCrO}_{4}{ }^{-}\right)$and $\mathrm{C}\left(\mathrm{CrO}_{4}{ }^{2-}\right)$ :

$$
\begin{gathered}
\mathrm{C}\left(\mathrm{HCrO}_{4}^{-}\right)=\mathrm{K}_{1} \mathrm{C}^{1 / 2}\left(\mathrm{Cr}_{2} \mathrm{O}_{7}^{2}\right) \\
\mathrm{C}\left(\mathrm{CrO}_{4}^{2-}\right)=\frac{K_{1}^{\frac{1}{2}} \mathrm{~K}_{2} \mathrm{C}^{\frac{1}{2}}\left(\mathrm{Cr}_{2} \mathrm{O}_{7}^{2-}\right)}{C\left(\mathrm{H}^{+}\right)}
\end{gathered}
$$

Equations 26, 27, 28 and 29 were used to calculate the concentrations of $\mathrm{Cr}_{2} \mathrm{O}_{7}{ }^{2-}, \mathrm{CrO}_{4}{ }^{2-}$ and $\mathrm{HCrO}_{4}{ }^{-}$ions for different chromium(VI) concentrations and solution $\mathrm{pH}$ values. For the equilibrium constants, $K_{I}$ and $K_{2}$, the values reported in Ref. 61-63 were used, and it was assumed that they did not significantly differ from the values for the solution tested in this experiment. The results are presented in Figure 7.

As shown in Figure 7, the concentration of $\mathrm{CrO}_{4}{ }^{2-}$ ions increases and concentrations of $\mathrm{Cr}_{2} \mathrm{O}_{7}{ }^{2-}$ and $\mathrm{HCrO}_{4}{ }^{-}$ions decrease with increasing $\mathrm{pH}$ of the solution.
Based on the values in Table II for $\mathrm{k}_{1}$ and $\mathrm{k}_{5}$ and the calculated concentrations of $\mathrm{Cr}_{2} \mathrm{O}_{7}{ }^{2-}, \mathrm{CrO}_{4}{ }^{2-}$ and $\mathrm{HCrO}_{4}{ }^{-}$ions, four sets of three Equations 24 were formed. Solving each set of equations provided values for $\mathrm{k}_{2}, \mathrm{k}_{3}$ and $\mathrm{k}_{4}$. Then, their means were calculated i.e. $\mathrm{k}_{2}=71.0 \mathrm{~mol}^{-2} \mathrm{dm}^{-6} \mathrm{~s}^{-1} ; \mathrm{k}_{3}=295.0 \mathrm{~mol}^{-2} \mathrm{dm}^{-6} \mathrm{~s}^{-1}$ and $\mathrm{k}_{4}=2922.5$ $\mathrm{mol}^{-2} \mathrm{dm}^{-6} \mathrm{~s}^{-1}$. The values show that the strongest catalytic effect on the disproportionation reaction was exhibited by $\mathrm{HCrO}_{4}{ }^{-}$ions, and the weakest by $\mathrm{Cr}_{2} \mathrm{O}_{7}{ }^{2-}$ ions.

Equation 24, the obtained $\mathrm{k}_{2}, \mathrm{k}_{3}$ and $\mathrm{k}_{4}$ values, and the calculated concentrations of $\mathrm{Cr}_{2} \mathrm{O}_{7}{ }^{2-}, \mathrm{CrO}_{4}{ }^{2-}$ and $\mathrm{HCrO}_{4}{ }^{-}$were used to determine the value of the rate constant $\mathrm{k}_{5}$. The results are listed in Table II.

The rate constant $\mathrm{k}_{5}$ as a function of $\mathrm{C}\left(\mathrm{Na}_{2} \mathrm{Cr}_{2} \mathrm{O}_{7}\right)$ and solution $\mathrm{pH}$ is plotted in Figures 8 and 9.

The results presented in Table II and the diagrams in Figures 8 and 9 show that the rate constant for the disporoportionation reaction increases as the concentration of chromium(VI) species and solution acidity increase. The $\mathrm{pH}$ of the solution has an indirect effect on $\mathrm{k}_{5}$ as the concentration of the catalytically most active species $\mathrm{HCrO}_{4}{ }^{-}$ increases with increasing acidity of the solution. 
a)

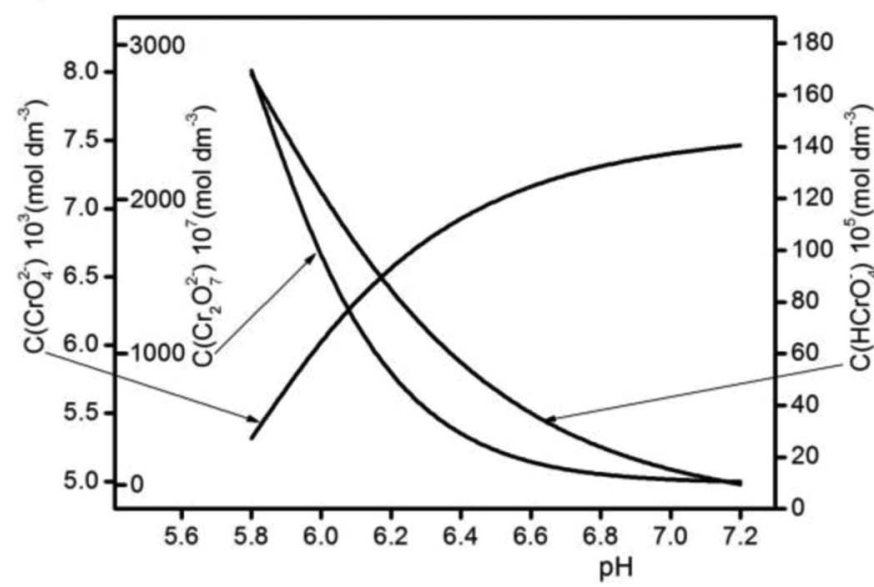

c)

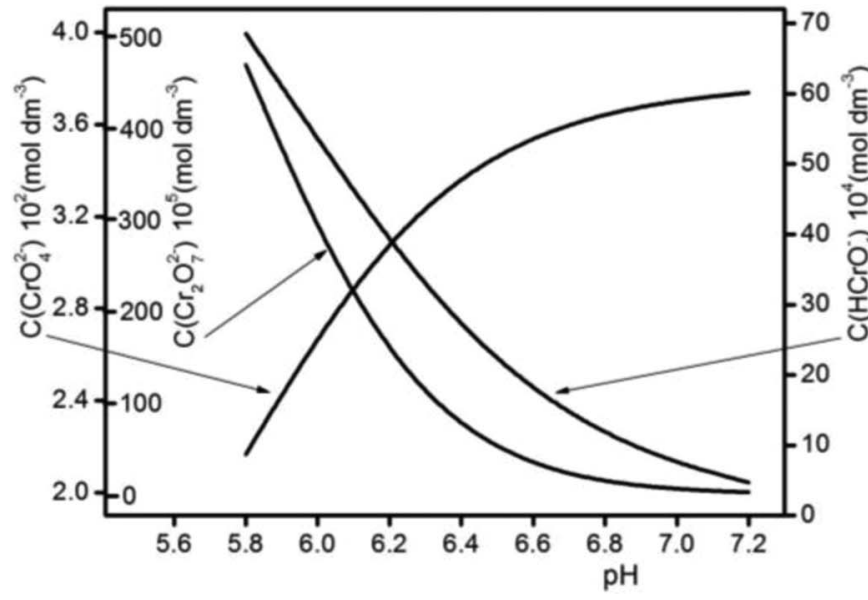

b)

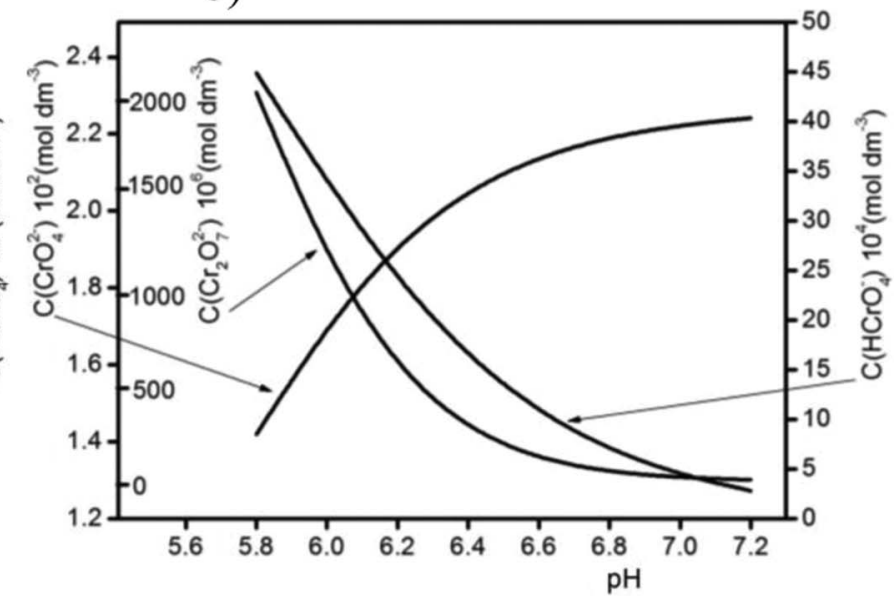

d)

Figure 7. Dependence of $\mathrm{C}\left(\mathrm{Cr}_{2} \mathrm{O}_{7}{ }^{2-}\right), \mathrm{C}\left(\mathrm{HCrO}_{4}{ }^{-}\right)$and $\mathrm{C}\left(\mathrm{CrO}_{4}{ }^{2-}\right)$ on solution pH and chromium( $\left.\mathrm{VI}\right)$ concentration, $\mathrm{C}\left(\mathrm{Na}_{2} \mathrm{Cr}_{2} \mathrm{O}_{7}\right)$ : a) . 0.00378 mol dm ${ }^{-3}$ $\left.\left.\mathrm{Na}_{2} \mathrm{Cr}_{2} \mathrm{O}_{7} ; \mathrm{b}\right) \cdots 0.011357 \mathrm{~mol} \mathrm{dm}^{-3} \mathrm{Na}_{2} \mathrm{Cr}_{2} \mathrm{O}_{7} ; \mathrm{c}\right) \cdots 0.01895 \mathrm{~mol} \mathrm{dm}^{-3} \mathrm{Na}_{2} \mathrm{Cr}_{2} \mathrm{O}_{7} ;$ and d $) \cdots 0.02650 \mathrm{~mol} \mathrm{dm}^{-3}(\mathrm{C}(\mathrm{NaCl}))=110 \mathrm{~g} \mathrm{dm}-3 ; \mathrm{C}\left(\mathrm{NaClO}_{3}\right)=540$ $\left.\mathrm{g} \mathrm{dm}^{-3}, \mathrm{t}=70^{\circ} \mathrm{C}\right)$.

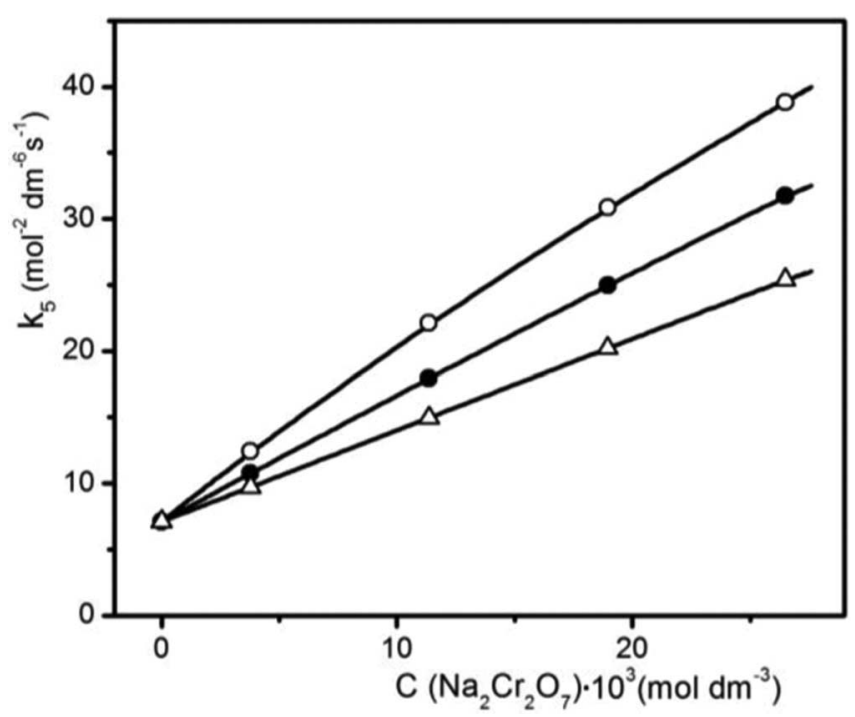

Figure 8. Rate constant $\mathrm{k}_{5}$ as a function of chromium(VI) concentration and solution $\mathrm{pH}: \circ \cdots \mathrm{pH}=6.0 ; \bullet \cdot \mathrm{pH}=6.4$ and $\Delta \cdot \cdot \mathrm{pH}=7.0(\mathrm{C}(\mathrm{NaCl})=$ $\left.110 \mathrm{~g} \mathrm{dm}^{-3} ; \mathrm{C}\left(\mathrm{NaClO}_{3}\right)=540 \mathrm{~g} \mathrm{dm}^{-3}, \mathrm{t}=70^{\circ} \mathrm{C}\right)$.

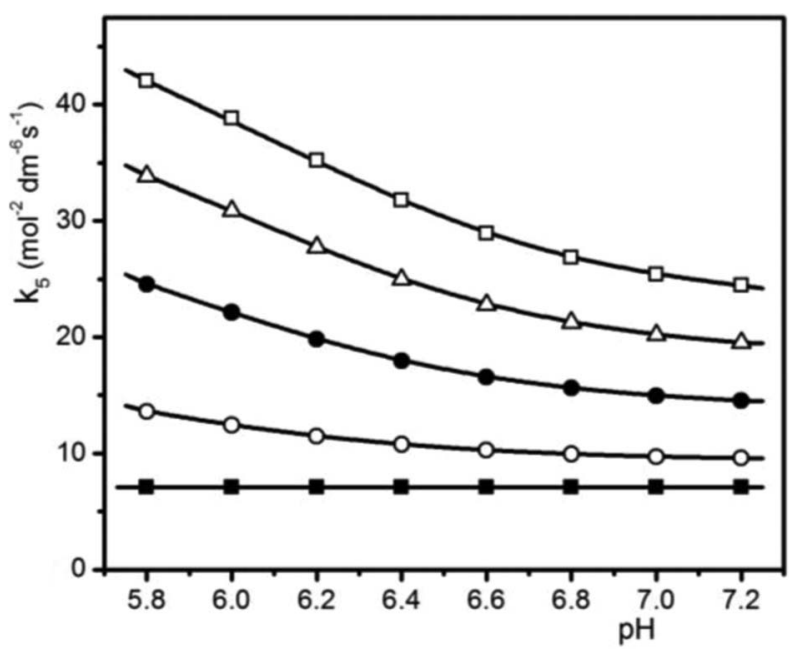

Figure 9. Rate constant $\mathrm{k}_{5}$ as a function of solution $\mathrm{pH}$ and chromium(VI) concentrations: $\mathrm{C}\left(\mathrm{Na}_{2} \mathrm{Cr}_{2} \mathrm{O}_{7}\right): \mathbf{a} .0 .00 \mathrm{~mol} \mathrm{dm}^{-3} \mathrm{Na}_{2} \mathrm{Cr}_{2} \mathrm{O}_{7} ; \circ \cdots 0.00378$ mol dm ${ }^{-3} \mathrm{Na}_{2} \mathrm{Cr}_{2} \mathrm{O}_{7} ; \bullet \quad 0.011357 \mathrm{~mol} \mathrm{dm}^{-3} \mathrm{Na}_{2} \mathrm{Cr}_{2} \mathrm{O}_{7} ; \Delta \cdots 0.01895 \mathrm{~mol}$ $\mathrm{dm}^{-3} \mathrm{Na}_{2} \mathrm{Cr}_{2} \mathrm{O}_{7} ; \boldsymbol{\Lambda} \cdots 0.02650 \mathrm{~mol} \mathrm{dm}^{-3} \mathrm{Na}_{2} \mathrm{Cr}_{2} \mathrm{O}_{7}\left(\mathrm{C}(\mathrm{NaCl})=110 \mathrm{~g} \mathrm{dm}^{-3}\right.$; $\left.\mathrm{C}\left(\mathrm{NaClO}_{3}\right)=540 \mathrm{~g} \mathrm{dm}^{-3}, \mathrm{t}=70^{\circ} \mathrm{C}\right)$. 
Under steady-state chlorate production conditions, at a constant $\mathrm{pH}$, steady-state concentrations of hypochlorous acid and hypochlorite are established, thus equalizing the production and consumption of hypochlorous acid and hypochlorite.

The production of hypochlorous acid and hypochlorite equals $\frac{I f}{2 F}$ where: I - current strength (A); $\mathrm{f}$ - the fraction of the anodic current efficiency for the oxidation of chloride ions (Reaction 1), and $\mathrm{F}$ - the Faraday constant $(\mathrm{F}=96480 \mathrm{~A}$ s). Hypochlorous acid and hypochlorite are consumed during several reactions, mostly through disproportionation (Reaction 4)..$^{1-15}$

The opinion of a number of authors ${ }^{7,10-13,16,17,29-31}$ is that substantial losses in current efficiency during the electrolytic chlorate process occur only due to the anodic oxidation of hypochlorous acid and hypochlorite (Reactions 7 and 8).

The current efficiencies measured using increments in chlorate concentration in the apparatus (Fig. 1) agreed to an accuracy of $\pm 0.6 \%$ with those determined based on the composition of the output gas mixture, using the expression based on Reactions 7 and 8. These results indicated that the current losses induced by Reaction 9 and by the anodic oxidation of water and $\mathrm{OH}^{-}$ions (Reactions 10 and 11, respectively) are negligible. Similar conclusions were drawn elsewhere..$^{10,33,35-37}$

Adding chromium(VI) to the electrolyte completely suppresses the reduction of hypochlorous acid, hypochlorite and chlorate (Reactions 14 and 15 , respectively) at the steel and titanium cathodes. ${ }^{1-7,15-17,41-47}$ Therefore, these hypochlorite losses can be completely neglected.

The consumption of hypochlorous acid and hypochlorite by homogeneous chemical reactions (Reactions 5 and 6 , respectively) is also negligible, ${ }^{23}$ as confirmed by the dependence between the current efficiency determined by measuring the increment of chlorate concentration and the current efficiency determined using the content of oxygen in the output gas mixture. Losses in hypochlorous acid and hypochlorite due to homogenous chemical Reactions 5 and 6 can be significant only if the electrolyte contains significant amounts of ions of some heavy metals. ${ }^{58-60} \mathrm{~J}$. Wanngård and M. Wildlock ${ }^{23}$ showed that, during the chlorate process, at $6.0 \leq \mathrm{pH} \leq 7.2$, the current losses caused by the desorption of chlorine and hypochlorous acid are negligible.

Given the above considerations, the following mole balance can be formed for hypochlorous acid and hypochlorite under steady-state chlorate production conditions:

$$
\frac{I f}{2 F}=\mathrm{Vk}_{5} \frac{K_{3} C^{2}\left(H^{+}\right)}{\left[K_{3}+C\left(H^{+}\right)\right]^{3}} \cdot \mathrm{C}^{3}\left(\mathrm{HClO}+\mathrm{ClO}^{-}\right)+\frac{I(1-f)}{F}
$$

where: $\frac{I(1-f)}{F}$ the amount of hypochlorite lost due to anodic oxidation (Reactions 7 and 8) (mol); V . t total volume of the solution $\left(\mathrm{dm}^{3}\right)$.

Rearranging Equation 30 gives:

$$
\frac{I(3 f-2)}{2 F V}=\frac{I \eta}{2 F V}=\mathrm{k}_{5} \frac{K_{3} C^{2}\left(H^{+}\right)}{\left[K_{3}+C\left(H^{+}\right)\right]^{3}} \cdot \mathrm{C}^{3}\left(\mathrm{HClO}+\mathrm{ClO}^{-}\right)
$$

As $(3 f-2)$ is the fraction of current consumed for chlorate production, $y=3 f-2$ is the anodic current efficiency for chlorate production. ${ }^{40}$

Based on Equation 31, $\mathrm{k}_{5}$ values (Table II) and $\mathrm{y}$ values (Table III), steady-state concentrations of hypochlorous acid and hypochlorite, $\mathrm{C}\left(\mathrm{HClO}+\mathrm{ClO}^{-}\right)$, were determined for different $\mathrm{pH}$ values and chromium(VI) concentrations. For calculation purposes, the value of $2 \cdot 10^{-7} \mathrm{~mol} \mathrm{dm}^{-3}$ was used for the hypochlorite equilibrium constant, $K_{3}{ }^{66}$ Assuming that $\mathrm{O}_{2}$ was generated only by the anodic oxidation of $\mathrm{HClO}+\mathrm{ClO}^{-}, \mathrm{y}$ values were determined using the expression $\eta=\frac{100-2 \times \% \mathrm{Cl}_{2}-3 \times \% \mathrm{O}_{2}}{100-\% \mathrm{Cl}_{2}-\% \mathrm{O}_{2}} .{ }^{66}$ The results obtained are presented in Table IV and Figure 10. For the sake of comparison, the experimental values of $\mathrm{C}\left(\mathrm{HClO}+\mathrm{ClO}^{-}\right)$are also presented.

As presented in Figure 10, the calculated values (Equation 31) practically coincide with the experimental results. This confirms the validity of the proposed mechanism of the catalytic disproportionation of hypochlorous acid and hypochlorite by chromium(VI) i.e. that the different chromium(VI) species $\left(\mathrm{Cr}_{2} \mathrm{O}_{7}{ }^{2-}, \mathrm{CrO}_{4}{ }^{2-}\right.$ and $\left.\mathrm{HCrO}_{4}{ }^{-}\right)$, whose concentrations are $\mathrm{pH}$-dependent, exhibit different catalytic

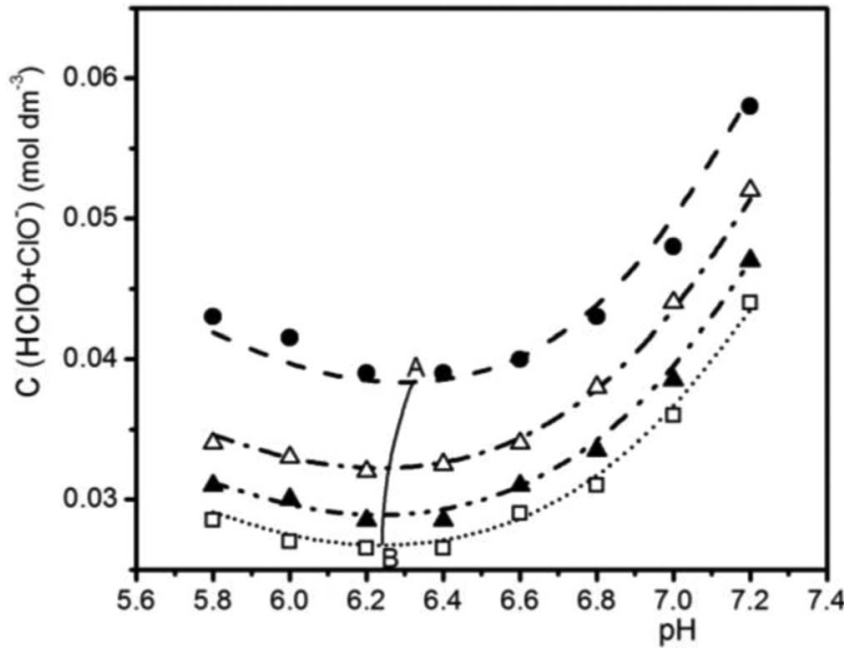

Figure 10. Steady-state concentrations of hypochlorous acid and hypochlorite, $\mathrm{C}\left(\mathrm{HClO}+\mathrm{ClO}^{-}\right)$, as a function of solution $\mathrm{pH}$ for different concentrations of chromium(VI), $\mathrm{C}\left(\mathrm{Na}_{2} \mathrm{Cr}_{2} \mathrm{O}_{7}\right)$ (curves showing the calculated values) (Equation 31, and symbols representing the experimental results):(-) and $\cdots 0.00378 \mathrm{~mol} \mathrm{dm}{ }^{-3} \mathrm{Na}_{2} \mathrm{Cr}_{2} \mathrm{O}_{7} ;(-\cdots-)$ and $\Delta \cdots 0.011357 \mathrm{~mol}$ $\mathrm{dm}^{-3} \mathrm{Na}_{2} \mathrm{Cr}_{2} \mathrm{O}_{7} ;(\cdots-)$ and $\boldsymbol{\Delta} \cdots 0.01895 \mathrm{~mol} \mathrm{dm}{ }^{-3} \mathrm{Na}_{2} \mathrm{Cr}_{2} \mathrm{O}_{7}$; and $(\cdots)$ and $\square \cdot 0.02650 \mathrm{~mol} \mathrm{dm} \mathrm{dm}^{-3} \mathrm{Na}_{2} \mathrm{Cr}_{2} \mathrm{O}_{7}\left(\mathrm{C}(\mathrm{NaCl})=110 \mathrm{~g} \mathrm{dm}^{-3} ; \mathrm{C}\left(\mathrm{NaClO}_{3}\right)\right.$ $=540 \mathrm{~g} \mathrm{dm}^{-3}, \mathrm{t}=70^{\circ} \mathrm{C}$ ).

effects. The established catalysis model indicates that disproportionation in the presence of chromium(VI) is a third-order reaction with respect to hypochlorous acid and hypochlorite, and a first-order reaction with respect to the chromium(VI) species. Based on the proposed catalysis model, it can be assumed that the chromium(VI) species $\left(\mathrm{Cr}_{2} \mathrm{O}_{7}{ }^{2-}, \mathrm{CrO}_{4}{ }^{2-}\right.$ and $\left.\mathrm{HCrO}_{4}{ }^{-}\right)$most likely do not change the sequence of elementary reactions in the disproportionation mechanism, but only lower the activation energy of the rate-determining step through interaction with its reactants. Probably as the result of the interaction, chromium(VI) species increase the Gibbs free energy of reactants or decrease the Gibbs free energy of products of the slowest elementary reaction in the disproportionation reaction mechanism, thus decreasing the activation energy.

The diagrams in Fig. 10 show a decrease in the catalytic effect of chromium(VI) with increasing $\mathrm{pH}$ of the solution. This decrease is due to the reduction in the concentration of the catalytically most reactive species $\mathrm{HC}_{\mathrm{r}} \mathrm{O}_{4}{ }^{-}$with increasing $\mathrm{pH}$ of the solution.

The optimal $\mathrm{pH}$ of the solution, in the absence of chromium(VI), for the maximum rate of disproportionation, is 6.4. At this $\mathrm{pH}$, the mole ratio of hypochlorous acid to hypochlorite is $2: 1$, which, in accordance with Equation 18, ensures the maximum rate of disproportionation. In the presence of chromium(VI), as its concentration increases, the optimum $\mathrm{pH}$ is shifted to lower $\mathrm{pH}$ values (curve A - B, Fig. 10). This occurs due to two effects: a) the increase in chromium(VI) concentration and the increase in solution acidity cause an increase in the concentration of the catalytically most active species $\mathrm{HCrO}_{4}{ }^{-}$, thus inducing a higher rate of disproportionation, and b) the decrease in $\mathrm{pH}$, at $\mathrm{pH}<6.4$, increases the ratio of hypochlorous acid to hypochlorite above $2: 1$, thus decreasing the rate of disproportionation. These two opposite effects cause a shift in the optimum $\mathrm{pH}$ to lower values with increasing concentration of chromium(VI), which is consistent with Equation 31.

Knowledge of the mechanism by which chromium(VI) affects different reactions in the electrolytic manufacture of chlorate ensures the optimization of the production process.

\section{Conclusions}

In the solution for the electrolytic production of chlorate, chromium(VI) catalyzes the disproportionation of hypochlorous acid 


\begin{tabular}{|c|c|c|c|c|c|c|c|c|}
\hline $\mathrm{C}\left(\mathrm{Na}_{2} \mathrm{Cr}_{2} \mathrm{O}_{7}\right) \mathrm{mol} \mathrm{dm}^{-3}$ & \multicolumn{8}{|c|}{0.00378} \\
\hline$\stackrel{\eta}{\mathrm{C}\left(\mathrm{Na}_{2} \mathrm{Cr}_{2} \mathrm{O}_{7}\right) \mathrm{mol} \mathrm{dm}^{-3}}$ & 0.938 & 0.940 & 0.950 & 0.946 & 0.940 & 0.930 & 0.924 & 0.900 \\
\hline $\begin{array}{c}\eta \\
\mathrm{C}\left(\mathrm{Na}_{2} \mathrm{Cr}_{2} \mathrm{O}_{7}\right) \mathrm{mol} \mathrm{dm}^{-3}\end{array}$ & 0.950 & 0.953 & 0.954 & 0.950 & 0.946 & 0.940 & 0.930 & 0.910 \\
\hline$\eta$ & 0.952 & 0.956 & 0.960 & 0.957 & 0.950 & 0.946 & 0.936 & 0.920 \\
\hline
\end{tabular}

\begin{tabular}{|c|c|c|c|c|c|c|c|c|}
\hline $\mathrm{C}\left(\mathrm{Na}_{2} \mathrm{Cr}_{2} \mathrm{O}_{7}\right) \mathrm{mol} \mathrm{dm}^{-3}$ & \multicolumn{8}{|c|}{0.00378} \\
\hline $\mathrm{C}\left(\mathrm{HClO}+\mathrm{ClO}^{-}\right) \mathrm{mol} \mathrm{dm}^{-3}$ exper. & 0.0430 & 0.0415 & 0.0390 & 0.0390 & 0.0400 & 0.0430 & 0.0480 & 0.0580 \\
\hline $\mathrm{C}\left(\mathrm{Na}_{2} \mathrm{Cr}_{2} \mathrm{O}_{7}\right) \mathrm{mol} \mathrm{dm}-3$ & \multicolumn{8}{|c|}{0.011357} \\
\hline $\mathrm{C}\left(\mathrm{HClO}+\mathrm{ClO}^{-}\right) \mathrm{mol} \mathrm{dm}^{-3}$ Eq. 31 & 0.0346 & 0.0328 & 0.0321 & 0.0324 & 0.0341 & 0.0375 & 0.0431 & 0.0514 \\
\hline $\mathrm{C}\left(\mathrm{HClO}+\mathrm{ClO}^{-}\right) \mathrm{mol} \mathrm{dm}^{-3}$ exper. & 0.0340 & 0.0330 & 0.0320 & 0.0325 & 0.0340 & 0.0380 & 0.0440 & 0.0520 \\
\hline $\mathrm{C}\left(\mathrm{HClO}+\mathrm{ClO}^{-}\right) \mathrm{mol} \mathrm{dm}^{-3}$ exper. & 0.0310 & 0.0300 & 0.0285 & 0.0285 & 0.0310 & 0.0335 & 0.0385 & 0.0470 \\
\hline $\mathrm{C}\left(\mathrm{Na}_{2} \mathrm{Cr}_{2} \mathrm{O}_{7}\right) \mathrm{mol} \mathrm{dm}^{-3}$ & \multicolumn{8}{|c|}{0.02650} \\
\hline $\mathrm{C}\left(\mathrm{HClO}+\mathrm{ClO}^{-}\right) \mathrm{mol} \mathrm{dm}^{-3}$ Eq. 31 & 0.0291 & 0.0273 & 0.0266 & 0.0269 & 0.0284 & 0.0314 & 0.0363 & 0.0435 \\
\hline $\mathrm{C}\left(\mathrm{HClO}+\mathrm{ClO}^{-}\right) \mathrm{mol} \mathrm{dm}^{-3}$ exper. & 0.0285 & 0.0270 & 0.0265 & 0.0265 & 0.0290 & 0.0310 & 0.0360 & 0.0440 \\
\hline
\end{tabular}

and hypochlorite, thus increasing the anodic current efficiency for chlorate production. The catalytic effect increases as chromium(VI) concentration and solution acidity increase. The species $\mathrm{Cr}_{2} \mathrm{O}_{7}{ }^{2-}$, $\mathrm{CrO}_{4}{ }^{2-}$ and $\mathrm{HCrO}_{4}{ }^{-}$coexist in the chromium(VI) solution. As the $\mathrm{pH}$ of the solution decreases, the concentration of $\mathrm{Cr}_{2} \mathrm{O}_{7}{ }^{2-}$ and $\mathrm{HCrO}_{4}{ }^{-}$ions increases and that of $\mathrm{CrO}_{4}{ }^{2-}$ ions decreases. In the absence of chromium(VI), disproportionation is a third-order reaction with respect to hypochlorous acid and hypochlorite. In the presence of chromium(VI), the reaction is both a third-order reaction with respect to hypochlorous acid and hypochlorite, and a first-order reaction with respect to the chromium(VI) species: $\mathrm{Cr}_{2} \mathrm{O}_{7}{ }^{2-}, \mathrm{HCrO}_{4}{ }^{-}$ and $\mathrm{CrO}_{4}{ }^{2-}$. The highest catalytic activity is exhibited by $\mathrm{HCrO}_{4}^{-}$ ions. Most likely, the chromium(VI) species do not change the sequence of elementary reactions in the disproportionation mechanism but only speed up the rate-determining step through interaction with reactants or intermediates. As chromium(VI) concentration increases, the optimum $\mathrm{pH}$ of the disproportionation reaction is shifted to an acid environment. This is due to an increase in the concentration of the catalytically most active species $\mathrm{HCrO}_{4}{ }^{-}$with increasing chromium(VI) concentration and solution acidity. Based on the experimental results and theoretical considerations, a mathematical model of the catalytic effect of chromium(VI) on the disproportionation of hypochlorous acid and hypochlorite into chlorate was set up. Good agreement was obtained between the theoretical and experimental values.

\section{Acknowledgments}

This study was financially supported by the Ministry of Education and Science of the Republic of Serbia through Project Ref. No. 172057.

\section{References}

1. IPTS/EC, Integrated Pollution Prevention and Control Reference Document on Best Available Techniques for the Manufacture of Large Volume Inorganic Chemicals Solids and Others industry, LVIC-S, Brussels, Belgium, (2007).

2. H. Vogt, J. Balej, J. E. Bennett, P. Wintzer, S. A. Sheikh, and P. Gallone, Ullmann's Encycl. Ind. Chem., p. 1, Wiley-VCH Verlag GmbH \& Co. KGaA, Weinheim, Germany (2000).
3. M. Grotheer, R. Alkire, R. Varjtan, V. Srinivasan, and J. W. Weidner, Electrochem. Soc. Interface, 15(1), 52 (2006).

4. S. S. L. Beraud, A. Gao, and S. Davis, Sodium Chlorate - HIS Chemical Economics Handbook, (2015).

5. H. Vogt, J. Balej, J. E. Bennett, P. Wintzer, S. A. Sheikh, P. Gallone, S. Vasudevan, and K. Pelin, Ullmann's Encycl. Ind. Chem., p. 1, Electronic Release, 7th ed., WileyVCH, Weinheim, Germany (2010).

6. J. E. Colman and B. V. Tilak, Encyclopedia of Chemical Processing and Design: Volume 51 - Slurry Systems: Instrumentation to Solid-Liquid Separation, J. J. McKetta Jr, Editor, 51, 126, Marcel Dekker, New York (1995).

7. N. Ibl and H. Vogt, Bockris J. O,B. E. Conway, E. Yeager, and R. E. White, Editors, vol. 2, p. 167, Comprehensive Treatise of Electrochemistry, Springer, Boston, MA (1981).

8. M. Spasojević, L. Ribić-Zelenović, and P. Spasojević, Ceram. Int., 38(7), 5827 (2012).

9. M. M. Jaksic, J. Electrochem. Soc., 121(1), 70 (1974).

10. M. Spasojević, N. Krstajić, and M. Jakšić, Surf. Techn., 21(1), 19 (1984).

11. A. R. Despić, M. M. Jakšsić, and B. Ž. Nikolić, J. Appl. Electrochem., 2(4), 337 (1972).

12. M. D. Spasojević, N. V. Krstajić, and M. M. Jakšić, J. Mol. Catal., 40(3), 311 (1987).

13. M. D. Spasojević, L. J. Ribić-Zelenović, P. M. Spasojević, and B. Ž. Nikolić, J. Serb. Chem. Soc., 79(6), 677 (2014).

14. K. Viswanathan and B. V. Tilak, J. Electrochem. Soc., 131(7), 1551 (1984).

15. H. Wendt, H. Vogt, G. Kreysa, D. M. Kolb, G. E. Engelmann, J. C. Ziegler, H. Goldacker, K. Jüttner, U. Galla, H. Schmieder, and E. Steckhan, Ullmann's Encycl. Ind. Chem., p. 1, Wiley-VCH Verlag GmbH \& Co. KGaA, Weinheim, Germany (2009).

16. D. Landolt and N. Ibl, Electrochim. Acta, 15(7), 1165 (1970).

17. M. M. Jaksic, A. R. Despic, I. M. Csonka, and B. Z. Nikolic, J. Electrochem. Soc., 116(9), 1316 (1969).

18. H. Imagawa, Denki Kagaku, 20, 571 (1952).

19. J. d'Ans and H. E. Freund, Z. Elektrochem., 61, 10 (1957)

20. T. Yokoyama and O. Takayasu, Kogyo Kagaku Zasshi, 70, 1619 (1967).

21. L. C. Adam, I. Fabian, K. Suzuki, and G. Gordon, Inorg. Chem., 31(17), 3534 (1992).

22. S. Sandin, R. K. B. Karlsson, and A. Cornell, Ind. Eng. Chem. Res., 54(15), 3767 (2015).

23. J. Wanngård and M. Wildlock, Chem. Eng. Res. Des., 121, 438 (2017).

24. M. W. Lister, Can. J. Chem., 34(4), 465 (1956).

25. M. W. Lister, Can. J. Chem., 30(11), 879 (1952).

26. M. W. Lister and R. C. Petterson, Can. J. Chem., 40(4), 729 (1962).

27. J. A. Church, Ind. Eng. Chem. Res., 33(2), 239 (1994).

28. L. C. Adam and G. Gordon, Inorg. Chem., 38(6), 1299 (1999).

29. N. Ibl and D. Landolt, J. Electrochem. Soc., 115(7), 713 (1968).

30. L. R. Czarnetzki and L. J. J. Janssen, J. of Appl. Electrochem., 22(4), 315 (1992).

31. L. Hammar and G. Wranglén, Electrochim. Acta, 9(1), 1 (1964).

32. S. Kotowski and B. Busse, Modern Chlor-Alkali Technology, 3(22) 310, K. Wall, Editor, Ellis Horwood, Chichester, (1986).

33. K. L. Hardee and L. K. Mitchell, J. Electrochem. Soc., 136(11), 3314 (1989).

34. P. Byrne, E. Fontes, O. Parhammar, and G. Lindbergh, J. Electrochem. Soc., 148(10), D125 (2001). 
35. R. K. B. Karlsson and A. Cornell, Chem Rev, 116(5), 2982 (2016).

36. N. Krstajić, V. Nakić, and M. Spasojević, J. Appl. Electrochem., 21(7), 637 (1991).

37. N. V. Krstajić, M. D. Spasojević, and M. M. Jakšić, J. Mol. Catal., 38(1-2), 81 (1986)

38. L. Nylén and A. Cornell, J. Appl. Electrochem., 39(1), 71 (2009).

39. B. Endrődi, N. Simic, M. Wildlock, and A. Cornell, Electrochim. Acta, 234, 108 (2017).

40. M. Spasojević, N. Krstajić, P. Spasojević, and L. Ribić-Zelenović, Chem. Eng. Res. Des., 93, 591 (2015).

41. B. V. Tilak, K. Tari, and C. L. Hoover, J. Electrochem. Soc., 135(6), 1386 (1988).

42. G. Lindbergh and D. Simonsson, Electrochim. Acta, 36(13), 1985 (1991).

43. A. A. Tidblad and J. Martensson, Electrochim. Acta, 42(3), 389 (1997).

44. K. Hedenstedt, A. S. O. Gomes, M. Busch, and E. Ahlberg, Electrocatalysis, 7(4), 326 (2016)

45. C. Wagner, J. Electrochem. Soc., 101(4), 181 (1954).

46. B. V. Tilak, K. Viswanathan, and C. G. Rader, J. Electrochem. Soc., 128(6), 1228 (1981).

47. I. Taniguchi and T. Sekine, Denki Kagaku, 43, 201 (1975).

48. G. Lindbergh and D. Simonsson, J. Electrochem. Soc., 137(10), 3094 (1990).

49. W. J. Clark and R. L. McCreery, J. Electrochem. Soc., 149(9), B379 (2002).

50. H. A. Duarte, K. Jha, and J. W. Weidner, J. Appl. Electrochem., 28(8), 811 (1998).

51. J. Wulff and A. Cornell, J. Appl. Electrochem., 37(1), 181 (2007),

52. V. I. Ginzburg and L. G. Tetereva, Russ. J. Electrochem., 8, 14 (1972).
53. V. I. Eberil, N. S. Fedotova, and E. A. Novikov, Russ. J. Electrochem., 33(6), 660 (1997).

54. V. I. Eberil, N. S. Fedotova, and E. A. Novikov, Russ. J. Electrochem., 33(5), 563 (1997).

55. Nylén and A. Cornell, J. Electrochem. Soc., 153(1), D14 (2006).

56. M. Macounová, N. Simic, E. Ahlberg, and P. Krtil, J. Am. Chem. Soc., 137(23), 7262 (2015).

57. E. Müller, Z. Elektrochem., 5(41), 469 (1899).

58. W. Lister, Can. J. Chem., 34, 479 (1956).

59. E. T. Gray, R. W. Taylor, and D. W. Margerum, Inorg. Chem., 16(12), 3047 (1977).

60. A. Hamano and H. Mori, Sasebo Kogyo Koto SenmonGakkoKenkyuHokoku, 14, 65 (1977).

61. J. W. Ball and D. K. Nordstrom, J. Chem. Eng. Data, 43(6), 895 (1998),

62. J. D. Ramsey, L. Xia, M. W. Kendig, and R. L. McCreery, Corros. Sci., 43(8), 1557 (2001).

63. F. Brito, J. Ascanio, S. Mateo, C. Hernández, L. Araujo, P. Gili, P. Martín-Zarza, S. Domínguez, and A. Mederos, Polyhedron, 16(21), 3835 (1997).

64. G. Gordon, R. G. Kieffer, and D. H. Rosenblatt, Prog. Inorg. Chem., 15, 201, S. J. Lippard, Editor, John Wiley \& Sons, Inc., Hoboken, NJ, USA (1972).

65. U. C. Lačnjevac, B. M. Jović, Lj. M. Gajić-Krstajić, J. Kovač, V. D. Jović, and N. V. Krstajić, Electrochim. Acta, 96, 34 (2003).

66. M. Jakšić, Faculty of Technology and Metallurgy, University of Belgrade, Serbia, PhD Thesis (1970). 